\title{
Seeing and Knowing in Detective Fiction: \\ The Case of Chinatown
}

\author{
By \\ Dino Koutras \\ B.A. Film Studies (High Honours) \\ Carleton University
}

A thesis submitted to the Faculty of Graduate Studies and Research in partial fulfillment of the requirements for the degree of

Master of Arts in Film Studies.

\author{
Carleton University \\ Ottawa, Ontario \\ August 2009 \\ (C) 2009, Dino Koutras
}


Library and Archives Canada

Published Heritage

Branch

395 Wellington Street Ottawa ON K1A ON4 Canada
Bibliothèque et

Archives Canada

Direction du

Patrimoine de l'édition

395, rue Wellington

Ottawa ON K1A ON4

Canada
Your file Votre reférence
ISBN: 978-0-494-58448-4
Our file Notre référence

ISBN: $978-0-494-58448-4$

\section{NOTICE:}

The author has granted a nonexclusive license allowing Library and Archives Canada to reproduce, publish, archive, preserve, conserve, communicate to the public by telecommunication or on the Internet, loan, distribute and sell theses worldwide, for commercial or noncommercial purposes, in microform, paper, electronic and/or any other formats.

The author retains copyright ownership and moral rights in this thesis. Neither the thesis nor substantial extracts from it may be printed or otherwise reproduced without the author's permission.
AVIS:

L'auteur a accordé une licence non exclusive permettant à la Bibliothèque et Archives Canada de reproduire, publier, archiver, sauvegarder, conserver, transmettre au public par télécommunication ou par l'Internet, prêter, distribuer et vendre des thèses partout dans le monde, à des fins commerciales ou autres, sur support microforme, papier, électronique et/ou autres formats.

L'auteur conserve la propriété du droit d'auteur et des droits moraux qui protège cette thèse. Ni la thèse ni des extraits substantiels de celle-ci ne doivent être imprimés ou autrement reproduits sans son autorisation.
In compliance with the Canadian Privacy Act some supporting forms may have been removed from this thesis.

While these forms may be included in the document page count, their removal does not represent any loss of content from the thesis.
Conformément à la loi canadienne sur la protection de la vie privée, quelques formulaires secondaires ont été enlevés de cette thèse.

Bien que ces formulaires aient inclus dans la pagination, il n'y aura aucun contenu manquant.

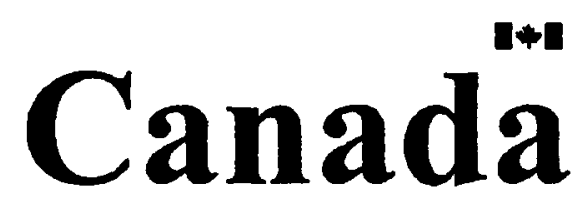




\begin{abstract}
This thesis presents an account of Chinatown (Roman Polanski, 1974) that reconsiders its historical significance relative to the genre of detective fiction. The framework I have devised defines this genre according to how it expresses the relationship between sight and knowledge, or what I term its "scopic assumptions."

Because of its inaugural status, I examine The Murders in the Rue Morgue by Edgar Allen Poe, and describe how early detective fiction promulgates the Enlightenment principle of firmly linking seeing and knowing in a causal relationship. With reference to The Maltese Falcon - both the novel by Dashiell Hammett and the 1941 film version by John Huston - and The Big Sleep — both the novel by Raymond Chandler and the 1946 film version by Howard Hawks, I then discuss the more tentative scopic assumptions of hardboiled fiction. Following a summary of the denigration of vision in the postmodern era, I describe an anti-ocular trend in detective films using The Long Goodbye (Robert Altman, 1973) as an illustrative text.

Within this framework, Chinatown's own scopic assumptions are subjected to analysis. The results suggest that Chinatown enacts a transition between two stages of detective fiction in a way that marks the film as a pivotal text in the history of the genre.
\end{abstract}




\section{Acknowledgements}

I would like extend a heartfelt thanks to Chris Faulkner, not only for the guidance and support he demonstrated in his role as advisor, but also for the infectious enthusiasm he regularly exhibits as a scholar and teacher. I would also like to thank the entire faculty and staff in the Carleton University Film Studies department, without whose generosity, support, and intellectual encouragement this project would not have seen the light of day. Professors Charles O'Brien and Mark Langer, each of whom served as graduate supervisor during my tenure in the program, deserve special mention for their tireless work on behalf of the graduate students.

I must also acknowledge the special rapport that developed amongst myself and my colleagues in the program as we were put through its rigours. It is a bond among peers I won't soon forget. To my friends and extended family, far too numerous to list, I hope you are all aware of the vital role your love and support played in this achievement. Finally to Emily, who supported me throughout this project in ways I cannot articulate and whom I love unconditionally, thank you. 


\section{Table of Contents}

Title Page

Abstract

Acknowledgements

Introduction................................................................................

Chapter One: The Bright Lights of The Rue Morgue..............................16

Chapter Two: The Dim Glow of Chandler's Mean Streets .......................41

Chapter Three: The Obscurity of Chinatown........................................69

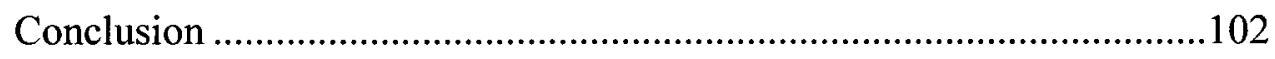

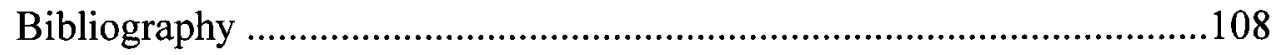




\section{Introduction}

There is no shortage of scholarship on Chinatown (Roman Polanski, 1974). Over the years the film has been the subject of numerous reviews, essays, journal articles, and book chapters. It also appears with conspicuous regularity on university syllabi, if anecdotal experience can be trusted. Yet despite this interest in the film and the profusion of scholarly material, interpretations of the cultural significance of Chinatown diverge very little from one account to the next. There is what might be called a standard account of the film, one that promulgates a specific message concerning its meaning. The standard account states that the film addresses, with uncanny precision, the then tumultuous socio-political climate of America. Indeed, its purported significance lies in how intuitively it seemed to mediate the disruptive forces re-shaping American society at that time, how it dramatized, in an allegorical way, the unsettled and unsettling state of the nation.

Chinatown's release date of June 1974 coincided with both the ongoing civil unrest over the war in Vietnam and the Watergate scandal—Richard Nixon resigned from the American presidency in August 1974. Given that the film's thematic interests are organized around moral and political corruption, there was, from the first, an inclination to evaluate Chinatown in light of this backdrop. For example, film historian Mark Horowitz states that "when the movie hit theatres in July 1974, unbridled pessimism was the order of the day. Political disillusion was epidemic." This sentiment is echoed in film

\footnotetext{
${ }^{1}$ Mark Horwitz, "Fault Lines," Film Comment 26, no 6 (Nov. 1990): 53.
} 
scholar David Lyon's contention that, at the time of the film's release, "structures of authority, social forms, were seen as noxious static, as agents of anger and chaos." ${ }^{2}$ In short, Chinatown's impeccable timing encouraged a now-cemented notion of the film as emblematic of the jaded, skeptical, and pessimistic mood gripping the nation in 1974.

The standard account outlined above turns on Chinatown's particular engagement with the generic conventions of hardboiled detective fiction. In particular, Chinatown purportedly interrogates the conventions of this genre in order to destabilize or even overturn its putative myth. This is, in fact, the central thesis of John Cawelti's "Chinatown and Generic Transformation in Recent American Films," arguably the most authoritative scholarly account of the film. Cawelti argues that Chinatown "deliberately invokes the basic characteristics of [the hardboiled genre] in order to bring its audience to see that genre as the embodiment of an inadequate and destructive myth." ${ }^{3}$ Other scholars such as James Maxfield corroborate this observation: Chinatown "embodies many of [the hard-boiled genre's] characteristic features for the ultimate purpose of critiquing its assumptions." ${ }^{\prime 4}$ The specifics of the myth in question vary from one account to the next but, in general, refer to the capacity of the hardboiled detective-hero to mete out justice in a pervasively corrupt society through a combination of rational deductive reasoning, toughness, and moral clarity. Thus, as the embodiment of this myth, the role of the

\footnotetext{
${ }^{2}$ David Lyons, "Flaws in the Iris," Film Comment 29, no 4 (July 1993): 49.

${ }^{3}$ John Calwelti, "Chinatown and Generic Transformation in Recent American Films," in Film Theory and Criticism, eds. Gerald Mast, Marshall Cohen, and Leo Braudy (New York: Oxford, 1992), 507.

${ }^{4}$ James Maxfield, "The Injustice of It All: Polanski's Revision of the Private Eye Genre in Chinatown," in American Fiction, Film, and Television, eds. Jerome H. Delamater and Ruth Prigory (Westport Conn.: Greenwood Press, 1998), 120.
} 
hardboiled detective is to act as a bulwark against the sinister and seemingly ubiquitous forces of corruption that haunt the urban landscape.

Through the depiction of its particular detective-hero, J.J. "Jake" Gittes, Chinatown supposedly refutes this myth. Cawelti, for one, argues that "the image of the heroic, moral action embedded in the traditional private-eye myth turns out to be totally inadequate to overcome the destructive realities revealed in the course of the story." Film scholar Bill Oliver contends that “the P.I.'s [Private Eye's] reintroduction does not coincide with a reaffirmation of the value of positive action" and that consequently "he has become an anachronism. ${ }^{16}$ Frequently, commentators make the direct connection to the socio-political events of mid-1970s America, as with Mary-Kay Gamel: "Gittes' mixture of selfishness and altruism, his misplaced heroics, and his inability to get beyond his own limited perspective make him a figure representative of American involvement in Vietnam." The general consensus is, therefore, that Chinatown disputes the foolhardy, almost dangerously romantic myth embedded in hardboiled fiction-- that one can still enact justice in our corrupt world — by vividly illustrating how corruption is not only pervasive, it is also implacable. This general analysis, which is endorsed in one form or another in almost all assessments of Chinatown, underpins the standard account of the film.

There was, perhaps, a certain inevitability concerning the way in which both critics and the general public responded to Chinatown, so uncannily did the events

\footnotetext{
${ }^{5}$ Calwelti, 503.

${ }^{6}$ Bill Oliver, "The Long Goodbye and Chinatown: Debunking the Private Eye Tradition," Literature/Film Quarterly 3, no. 3 (Summer 1975): 240.

"Mary-Kay Gamel, "Chinatown," in Classical Myth and Culture in the Cinema, ed. Martin M. Winkler (Oxford: Oxford University Press, 2001), 167.
} 
depicted in the film echo their own domestic circumstances. Yet, despite the congruence between Chinatown and real world events, this account, on closer inspection, contains a fateful defect, one which originates in the presumed assumptions of the hardboiled myth that inform such a reading. More precisely, although the standard account correctly posits the hardboiled genre as the decisive reference point for its interpretation of Chinatown, it rests on a distorted conception of the myth that the film allegedly invokes and overturns. The standard account does not consider hardboiled fiction in all its ambiguity and contradictions, but depends instead on what may be characterized as a shallow and stereotyped reading of the genre. In other words, the underlying reasoning of the standard account is sound but the supposition that it relies upon is somewhat faulty, calling into question the very validity of the entrenched critical stance that sustains most assessments of Chinatown.

There is also a second problem with the standard account: the methodology is too narrowly focused on the relationship between Chinatown and the hardboiled genre with a concomitant neglect of the broader history of detective fiction. In Chinatown, references to hardboiled conventions, as they crystallized in both the literature and cinema of interwar America, are rather explicit, marking an obvious entry point when assessing the film. One can't help but consider hardboiled fiction when engaging with Chinatown as the nature of the film unmistakably encourages such an approach. However, so deliberately did the filmmakers invoke the genre that the relationship between the two seems to have stifled a more expansive analysis. Modern detective fiction, of which the hardboiled school is only one variety, one stage in the development of the genre as a 
whole, has a history that stretches back to the work of Edgar Allen Poe in the mid-19th century. Although part of this long tradition, Chinatown's place relative to it has long been ignored.

It comes as no surprise that woven into the argumentation of the standard account is a kind of eulogy for the hardboiled genre, as if by 1974 it had exhausted itself and a film like Chinatown was a testament to its demise. In his account, Calwelti suggested at the time that the traditional genres of American cinema (of which the hardboiled genre is his focus) and the cultural myths they embody, "are no longer fully adequate to the imaginative needs of our time." An even stronger statement on this point comes from film scholar Stephen Cooper, who asserts that with Chinatown the genre "can be said effectively to have investigated and incriminated itself." "Although a post-mortem of the hardboiled genre flows naturally from the standard account of the film, history has proven this prediction wrong. In both literature and cinema, the genre continues to enjoy widespread currency, despite films like Chinatown in the 1970s which seemed to signal that it had reached a dead end. Authors like Elmore Leonard and James Ellroy continue to churn out critically and commercially successful hardboiled fiction that updates the genre in interesting ways, while the release and positive reception of films like The Big Lebowski (Coen Brothers, 1996), Kiss Kiss, Bang Bang (Shane Black, 2005), and Brick (Rian Johnson, 2006) indicates that the genre is far from exhausting itself. In fact, the wide-spread popularity of detective fiction on television, some of it inflected by a

\footnotetext{
${ }^{8}$ Calwelti, 511 .

9 Stephen Cooper, "Sex/Knowledge/Power in the Detective Genre," Film Quarterly 42, no. 3 (Spring, 1989): 23.
} 
hardboiled ethos, speaks to its continued viability. What those gloomy forecasts for the genre reinforce is that the standard account rests on a faulty perception of traditional hardboiled fiction.

In light of these considerations, it becomes apparent that, although it has inspired bountiful scholarship, there are aspects of Chinatown that have either been misinterpreted or insufficiently explored. Accordingly, what is required is a critical re-consideration of the film, one where the shortcomings of the established scholarly assessments are taken into account and, so far as possible, redressed. This thesis, written in that spirit, offers a more comprehensive account of Chinatown, one that reconsiders the hardboiled genre's mythic elements, while also addressing Chinatown's relationship to the broader trajectory of detective fiction. Such an analysis will, I hope, rectify misperceptions concerning the meaning of the film, and, at the same time, clarify its historical significance.

What this approach to the film reveals is that Chinatown is informed by a visually-based epistemolgy—its underlying scopic assumptions—-that is unique among detective fiction. Several of the more insightful accounts of Chinatown remark on this aspect of the film, but typically in the service of supporting the faulty claim that the film overturns the hardboiled myth, and even in these cases the relevance of this dimension is marginal and under-explored. Once the critical framework is adjusted along the lines I have suggested, this particular aspect of Chinatown comes to the fore and reveals itself as perhaps the film's most salient feature. My analysis will thus focus on a comprehensive exploration of Chinatown's scopic assumptions relative to the wider field of detective fiction. The results of this analysis suggest that, in relation to issues of seeing and 
knowing, the film can be considered a pivotal text, demarcating one stage of detective fiction with another.

In order to support this claim it is necessary to provide a theoretical foundation that establishes visuality's role in the epistemological climate within which modern detective fiction functions. Drawing on the work of Martin Jay and Jonathan Crary, both of whom have contributed rigorously researched scholarship to the field, I hope to demonstrate that how we see is not a fixed matter, but rather that it is contingent on a particular scopic regime and that this regime plays a crucial role in how we produce and acquire knowledge. I also intend to demonstrate how detective fiction anchors itself epistemologically to the dominant scopic regime of its time, and how its own thematic concerns adjust themselves according to shifts in the visual order within which it is produced. Although these points will be thoroughly elaborated as I make my case in the later chapters, I would like to supply a brief outline of some of the theoretical issues surrounding vision and its relationship to knowledge that will come into play, and then link them back to detective fiction.

The notion of an a priori mode of observation, of an experience of seeing that takes place devoid of context or in a climate that lacks a point of reference, has been effectively discredited by scholars such as Jay and Crary. They have also discredited the notion that there is a homogeneous, transhistorical mode of observation, universal in scope and static in nature. In place of these views, they have persuasively argued that how we see is in many ways determined by external and variable forces, that the act of 
observing is contingent on a whole slew of conditions that are beyond our immediate awareness. The key insight they have generated is that context not only contributes to the experience of seeing, it is foundational. In elaborating this point, Crary states that "an observer is one who sees within a prescribed set of possibilities, one who is embedded in a system of conventions and limitations." ${ }^{10}$ The system itself is determined by a complex permutation of forces, among them: discursive, social, cultural, and technological. Needless to say, the system of conventions and limitations within which we, as observers, are embedded is not fixed since the forces that determine a particular mode of observation are themselves unstable. The structural make-up of societies changes, their cultural values modify, their technology develops, and how their members see shifts accordingly. Occasionally there is a relatively dramatic shift in the dominant scopic regime of a society, one that can be said to constitute a significant reconfiguration of its predecessor. Here our attention turns to the emergence of the Enlightenment, its influential principles, and the consequences for visuality that its advent entailed.

The Enlightenment is generally considered to constitute a decisive turning point in the history of Western civilization. It should come as no surprise that with its arrival arose a new way of seeing. At the heart of the Enlightenment was a broad-based movement away from an ecclesiastical and monarchical frame of reference towards the emergence (or re-emergence) of reason as a guiding virtue. ${ }^{11}$ Indeed, the most basic difference that sets the era of the Enlightenment apart from its predecessor is how reason

\footnotetext{
${ }^{10}$ Jonathan Crary, Techniques of the Observer: On Vision and Modernity in the Nineteenth Century (Cambridge Mass.: MIT Press, 1990), 6.

${ }^{11}$ See Roy Porter, The Enlightenment (Basingstoke, Hampshire: Palgrave, 2001).
} 
and its application were adopted as the dominant principle guiding the development of human affairs. The Enlightenment was, as much as anything, the result of an emancipatory impulse that found in rational human discourse a potent means for achieving salvation, for freeing humanity from the bondage imposed by church and king.

Out of the nacent constellation of strategies that emerged towards these ends, some looked to the past and discovered, in ancient Greek and Roman civilization, a desirable and viable model to emulate, which would replace the outdated medieval one which had dominated for so many centuries. As classical systems of thought were recuperated, sight, which had had a privileged position during Greek and Roman antiquity, was restored to a position of prominence among the senses, particularly in relation to the acquisition of knowledge. ${ }^{12}$ The most overt realization of its return to prominence is undoubtedly the Rennaissance development of linear perspective in painting. The technique of rendering three-dimensional space onto a two-dimensional flat surface using Euclidian principles proved to be more than just an aesthetic turn from medieval imagery; it registered a new way of experiencing and understanding the objective world that was inextricably linked to visuality.

If we can designate an individual who hovers over the birth of the Enlightenment, one of the prime candidates would surely be René Descartes, who gave perhaps the most articulate voice to this epochal change. The significance of his contributions during this period is such that his writings are sometimes used to demarcate the dawn of the Enlightenment itself. Though his contributions were diverse, they were all inflected by a

\footnotetext{
${ }^{12}$ See Chapter 1 of Martin Jay's Downcast Eyes: The Denigration of Vision in Twentieth-Century French Thought (Berkeley: University of California Press, 1994).
} 
deep-seated ocularcentrism. This partiality for the sense of sight is plainly expressed by Jay who states that Descartes was "a quintessentially visual philosopher, who tacitly adopted the position of a perspectivalist painter...to reproduce the observed world." ${ }^{13}$ His visual bias was particularly pronounced in the sphere of scientific discourse. Woven throughout his ideas, which were to play an integral role in the ensuing epistemological order, was the notion that comprehension of the external world was heavily reliant on its visual appraisal, that the production of empirical knowledge was dominated by the act of observation. Descartes came to posit a structure of the mind and then assumed it was congruent with the external world in a specular way, a precept so influential that it still resonates strongly today. Thus, as Jay notes, "[Descartes] is...often seen as legitimating a mode of scientific investigation through visual observation of evidence, which could lead in a decidedly empirical direction." ${ }^{14}$ Readily taken up all over the Western world, Cartesian Perspectivalism ${ }^{15}$ would be cemented as the dominant scopic regime of the modern era and the epistemological order that sustained it.

Although it would be decidedly overstating the case to suggest that modern detective fiction would not have developed without Descartes and his influence, the rationalization of sight that emerged during the Enlightenment, and that he articulated with such clarity, remains one of the fundamental constitutive elements of the genre. Through its actions and plotting, detective fiction dramatizes the relationship between sight and knowledge, and through its thematic interests it explores the implications and

\footnotetext{
${ }^{13}$ Ibid., 69.

${ }^{14}$ Ibid., 71.

${ }^{15}$ This is Jay's term, coined in Downcast Eyes.
} 
consequences of how we link the two. No other genre of fiction has done the same with such precision and depth, nor does one exist that has the same capacity to do so. If detective fiction can be understood as a profound meditation on the supposedly causal relationship between sight and the acquisition of knowledge, as I suggest, then we arrive at the conclusion that its conventions and concerns are determined by its underlying scopic assumptions. In addition, we must also conclude that any modifications in the scopic field from which it springs are registered in detective fiction via changes to these same convention and concerns.

Earlier, I made the point that how we see is not a fixed matter, and I would like to stress that this dictum applies equally well to the mode of observation I have described as Cartesian Perspectivalism. Despite its historical dominance, the systems of conventions and limitations that shape it have been subjected to shifts in society, cultural modifications, and technological developments, and the regime has evolved in response. At various points during its reign, critics disparaged its prominent status, alternative models emerged that threatened its dominance, technology was invented that forced it to adapt. In each case, our particular mode of observation changed accordingly, sometimes slightly, but sometimes more dramatically. The exhaustive studies of both Jay and Crary indicate that the rising prominence of sight in the epistemological order reached its apex during the $19^{\text {th }}$ century, but that since that time the trend has reversed itself and confidence in its hegemonic authority has waned to the point where denigration now greets this once noble sense. In striking ways, the evolution of detective fiction has paralleled the rise and fall of this trajectory. It is within this critical framework that I hope 
to demonstrate how Chinatown plays out its pivotal role in the evolution of detective fiction, how it manages to address, so effectively, a shift in the dominant scopic regime by linking one visual order with another in one coherent text.

The thesis is structured chronologically, beginning with the earliest detective fiction and ending with the most recent. Each chapter describes a particular visual order before proceeding to an analysis of specific texts. The first chapter focuses on the rise of Cartesian Perspectivalism and its influence on the development of classical detective fiction. Edgar Allen Poe's short story The Murders in the Rue Morgue is used as the central illustrative text, with particular emphasis placed on the story's treatment of visuality. The analysis of Poe's story is also supplemented by references to the Sherlock Holmes stories of Sir Arthur Conan Doyle. The second chapter is organized around the scopic uncertainty that took hold as Cartesian Perspectivalism faltered as the dominant visual order, and how, subsequently, the scopic assumptions of detective fiction adapted to this uncertainty in the form of the hardboiled genre. The central texts that will be scrutinized in this chapter are The Maltese Falcon—both the novel by Dashiell Hammett and the 1941 film version by John Huston—and The Big Sleep—both the novel by Raymond Chandler and the 1946 film version by Howard Hawks. The third and final chapter chronicles the denigration of vision in the postmodern era, and is followed by examples of the ways in which postmodern detective fiction registered this scopic denigration. A brief look at the 1973 film The Long Goodbye by Robert Altman precedes an indepth analysis of the intricate scopic assumptions of Chinatown. 
This thesis focuses on detective fiction in its quintessentially American form and, aside from brief references to French and English examples, neglects other national detective fiction traditions. Since the central object of study in this thesis is Chinatown, the American tradition necessarily dominates the research and subsequent analysis. As part of the same strategy, I have attempted to focus on those texts that had the most impact on Chinatown - hence the inclusion of The Maltese Falcon and The Big Sleep for textual analysis at the expense of other hardboiled stories. As I elaborate in the second chapter, these two narratives are the dominant touchstones for Chinatown. The Long Goodbye is included in the third chapter in order to give a sense of the types of trends in American detective fiction during its postmodern phase in a way that complements the analysis of Chinatown.

Although the literature on Chinatown is rather vast, four articles pertaining to the film are of particular interest to this thesis. In addition to Cawelti's "Chinatown and Generic Transformation in Recent American Films," which I have already commented upon, I am indebted to David Lyons" "Flaws in the Iris: The Private Eye in the Seventies." Although Lyons' account is perhaps the one that best engages with the motif of sight as it is thematically developed in Chinatown, it neither examines comprehensively the operation of this motif in the film, nor does it contextualize visuality as a theme relative to the tradition of the detective genre. The epistemological implications of Chinatown's scopic assumptions — the core subject of this study—are only briefly touched upon in his account. Lyons' interest lies more in putting Chinatown into contact with The Long Goodbye; the issue of visuality is the alibi that brings them 
together. However, in the third chapter of this thesis, Lyon's essay affords a useful starting point from which to advance a more comprehensive assessment of the film. Also of note is Mary-Kay Gamel's chapter "Chinatown" in Classical Myth \& Culture in the Cinema. Gamel's account, which is organized around explicating Chinatown's staging of the Oedipus Myth, is insightful and comprehensive, although she disappointingly misreads the visual dimension of the film. Finally, Mark Horowitz's article "Fault Lines," which assesses the career of Chinatown's screenwriter Robert Towne, provides me with useful insights concerning the film's unique place in the screenwriter's oeuvre.

In terms of the literature on visuality, I rely heavily on Jay's Downcast Eyes: The Denigration of Vision in Twentieth-century French Thought. This book recounts, in minute detail, the role of vision in Western epistemology from the time of classical Greece up to the late $20^{\text {th }}$ century. Many of the terms and concepts I use in regards to visuality, such as "scopic regime," I have borrowed from Jay's book. I would also like to mention the contribution of Jonathan Crary's Techniques of the Observer: On Vision and Modernity in the Nineteenth Century, an equally rigorous treatise on vision that complements Jay's account. Together, these two scholars have provided the proper theoretical foundation for the central issues raised in this thesis.

Although Chinatown is the declared focus of the thesis, its direct analysis only begins midway through the third and final chapter. There are two reasons for this imposed delay. The first is that, in order to fully comprehend the implications of the film's underlying scopic assumptions, it is important to establish how this dimension of detecive fiction has been realized historically. Since no study on the subject yet exists, it 
has been necessary to produce one here, if only in a schematic way. As for the second reason, it goes to a more general philosophy regarding the analysis of cultural texts. I conceive this undertaking as akin to an archeological operation, where the stress is on discovering the various historical layers that lie latent in the work. Chinatown, as primarily a product of the historical development of detective fiction, can best be explicated by unearthing its buried past in relation to its generic heritage. It is a methodological approach that I have embraced because, as I hope this thesis proves, the results can be especially illuminating. 


\section{The Bright Lights of The Rue Morgue}

Since its inception, one of the central thematic concerns of detective fiction has been organized around elaborating the implications of a visually biased epistemology. Through a close study of The Murders in the Rue Morgue by Edgar Allen Poe-the very first detective story and the prototype for the genre-it will be demonstrated how detective fiction was initially ingrained with underlying scopic assumptions that forge a direct link between seeing and the acquisition of knowledge. However, before we get to Poe and the classical detective genre he inaugurated, we must first revisit and elaborate some of the theoretical issues organized around visuality that were raised in the introductory chapter.

There is a long, though inconsistent, tradition in the West of structuring a visual bias into our systems of knowledge. In his seminal essay "The Nobility of Sight," Jonas describes how sight came to be the most valued sense in classical Greek thought due to what appeared to be its natural capacity to promote abstract reasoning. In disclosing his own visual bias, Jonas argues that sight distinguishes itself from other senses in the way it favours a perceptual unity—whole, static, infinite - over a perceptual succession — partial, transient, limited—and an experience of separation over one of engagement. In contrast to the other, temporally based senses, the perceptual field of vision can be apprehended in an instant, allowing the perceiver to compare and

\footnotetext{
${ }^{16}$ Hans Jonas, "The Nobility of Sight" in Philosophy and Phenomenological Research 14, no. 4 (Jun,. 1954), pp 507-519.
} 
interrelate, to grasp immediately juxtapositions and proportions. Furthermore, the apparent separation between subject and object- the impression of ontological distinction between the two-was reinforced primarily through the sense of sight. For Jonas, the concept of objectivity, "of the thing as it is in itself as distinct from the thing as it affects me," ${ }^{17}$ emerges naturally from the particular qualities of vision, and "from this distinction arises the whole idea of theoria and theoretical truth" ${ }^{\text {"18 }}$ that was to play such a vital role in classical Greek thought. Objectivity leads conceptually to abstractions, which lead inevitably to theorizing and philosophy. Though perhaps over-extending his reasoning, Jonas makes the persuasive case that the epistemology of the classical era operated according to this visual logic.

Between the classical era and the Enlightenment stretched the vast, less visually inclined—-some would say anti-ocular—period of the Dark and Middle Ages, a period in which the light of reason was effectively dimmed. The ecclesiastical and monarchical model that took hold in the West cast sight down from the privileged position the Greeks had granted it. The power wielded by church and king over human affairs during this time was absolute, leading to a pervasive state of oppression. In this context, the project of movements like the Renaissance and the Enlightenment can be perceived as the struggle to liberate humanity from the subjugation imposed by medieval social and political structures. One of the more widely adopted strategies towards these ends was a revival of classical ideals, and perhaps the most important of these was the application of reason as a guiding principle in human affairs. Rational human discourse, reintroduced

\footnotetext{
${ }^{17}$ Ibid., 515.

${ }^{18}$ Ibid.
} 
into general practice, provided the most potent weapon in the campaign for liberation. Not coincidentally, along with the return of reason to an esteemed position came the revival of another classical feature: the valorization of vision.

The first wave of what was to become a resurgent ocularcentrism appeared in the sphere of art. Perspective painting, which depended more on optical principles than did the religious symbolism characteristic of medieval imagery, represented space in an illusory three dimensions from a single, secular vantage point. Perspective came to dominate visual practice of the Renaissance and was to play a fundamental role in shaping the new scopic regime of the Enlightenment. ${ }^{19}$ The implications of perspectival vision defy easy summary, but I would like to stress a few salient points. Perspectival art came to be described by the celebrated metaphor of a "transparent window" on the world. ${ }^{20}$ What this metaphor suggests is that art of this kind thrusts the individual beholder to the privileged centre of vision. In contrast to the divinely inspired, multiple viewpoints of medieval art, this new technique put a premium on the actual visual field of the human perceiver. The metaphor of the window also suggests that the external world was separated from the seeing subject, cleaved from a more intimate relationship with it. Perspectival art tacitly endorsed an impression of the world as a distinct object, available to be observed with supreme detachment from a distance.

Taken together, these aspects of perspectivalism indicate a new understanding of the relationship between perceiver and perceived—between the eyes and what they

\footnotetext{
${ }^{19}$ Although perspective tends to dominate historical accounts, there were other parallel aesthetic traditions. Jay specifically points out the Dutch art of describing as an alternative practice, but he stresses the dominance of perspective.

${ }^{20}$ Attributed by Jay to Leon Battista Alberti in De pictura (1435).
} 
beheld - that many commentators suggest established the foundation of the scientific revolution that the West was to experience in the latter part of the Enlightenment. Jay, for instance, notes that perspective painting assumed that what was visible in the perceptual field was a homogenous, regularly ordered space, one that could be duplicated by the extension of a grid-based network of coordinates. In this conception, that which is seen by human eyes - the whole panorama of the visual field—could henceforth be construed as visual evidence. William Ivins, who wrote the influential treatise $O n$ the Rationalization of Sight, offers the most radical position on the matter. He states that perspective "may be regarded as the application to pictorial purposes of the ... basic assumptions underlying all the great scientific generalizations, or laws of nature.,2I Whatever its specific influence, there is persuasive evidence that the new understanding of space engineered by perspectivalism was, at the very least, quite congenial to a scientific world-view.

Along with the advent of linear perspective in painting, the hegemony of the visual was assured by the full flowering of the Enlightenment. Salvaged from classical Greek thought during this time was the linkage between lucidity and rationality-a pairing to which the Enlightenment owes its very name. The great scholar of the era, Jean Starobinski, summarized this new epistemological order with fine precision: "Such was the century of the Enlightenment which looked at things in the sharp clear light of the reasoning mind whose processes appear to have been closely akin to those of the seeing

\footnotetext{
${ }^{21}$ William M. Ivins Jr., On the Rationalization of Sight (New York: De Capo Press, 1973), 10-11.
} 
eye. ${ }^{222}$ Although the project of the Enlightenment cannot be reduced to the efforts of a single individual, there is one figure who dominates the discursive field around which it developed. René Descartes gave clear and articulate expression to the emerging system of knowledge that was supplanting the old, and through his writings we get a sense of just how vital a role visuality was to play in this new order. Descartes famously wrote about optics itself, but his interest in vision went beyond the mere physics of seeing, evolving to become what one observer characterized as "a campaign for a visually conceived cognitive enterprise. ${ }^{, 23}$ Given the extent of his output, only a summary of his relevant thoughts on vision is possible here, but with that proviso in mind I intend to outline the broad strokes of what Jay describes as "the Cartesian contribution to the dominant ocularcentric bias of the modern era," whose influence, he goes on to suggest, "was assuredly profound., 24

If we were to assign a guiding intent to Descartes' body of work, one that ties together its various strands, a likely candidate would be his desire to develop a rigorously theorized model of knowledge. The starting point in this enterprise—indeed, the bedrock of his theories - was his acknowledgement of our innate capacity for reason, a trait that he likened to a "great light in the intellect. ${ }^{, 25} \mathrm{He}$ theorized that this rational illumination was dependent on the cognitive processing of direct perceptual experiences. For Descartes, the point where perception was rendered into a "transparent clarity of

\footnotetext{
${ }^{22}$ Jean Starobinski, The Invention of Liberty, 1700-1789, trans. Bernard C. Swift (Geneva: Skira, 1964), 210.

${ }^{23}$ Walter J. Ong, The Presence of the Word (New York: Global Academic Publishing, 2000), 221.

${ }^{24}$ Jay, 80.

${ }^{25}$ René Descartes, The Philosophical Writings of Descartes, vol 2, trans. John Cottingham, Robert Stoothoff, Dugald Murdoch (Cambridge: Cambridge University Press, 1984), 134.
} 
cognition" was the moment of certainty, and certainty was the foundation of knowledge. ${ }^{26}$ Though his writings make clear that the eyes were the most valued perceptual organs in this process, the visual logic of his rationale extended beyond sight and into the realm of imagination. Descartes postulated that, as part of the cognitive process, our capacity for rational illumination empowered us to make judgments of our perceptual experiences in a way that transformed them into images. As images they were open to be scrutinized with our "mind's eye." In this way, the notion of divine apprehension that dominated the medieval era was displaced, superceded by a model of knowledge that trusted in the generation of rational insights derived from the observations of a seeing subject, peering out from behind his or her eyes. Descartes' conceptual turn meant the autonomization of the subjective perceiver from the external world, which was now reduced - as in perspectivalism - to a neutral, observable object. Between perspectival art and the discursive contributions of Descartes, a new scopic regime had emerged, part of a burgeoning epistemological order that granted unparalleled primacy to vision. The new regime has since been given the apt moniker Cartesian Perspectivalism.

Cartesian Perspectivalism was a new way of looking at the world. The vantage point it assumed was distant, disincarnated and masterful—it was the commanding view from above, gazing down with appraising and detached interest on all that was surveyable. This new scopic regime seemed to offer the seductive prospect of seeing the complete picture - absolute knowledge — in a snapshot. In addition to a totalizing

${ }^{26}$ Ibid., 135. 
viewpoint, it implicitly promised control and empowerment over the objects enclosed in its perceptual field. Swift advances in the arts and sciences were made under its influence that seemed to justify faith in its efficacy. Jean le Rond d'Alembert in describing the ambitious goals of the Encyclopédie - which he co-edited with Denis Diderot, and which was itself an attempt at a totalizing knowledge - elegantly illustrates the aspirations of Cartesian Perspectivalism:

The general system of the sciences and arts is a sort of labyrinth...The encyclopedic arrangement of our knowledge...consists of...placing the philosopher at a vantage point, high above this vast labyrinth, whence he can perceive the principle sciences and arts simultaneously. From there he can see at a glance the objects of their speculations and the operations which can be made on these objects. ${ }^{27}$

According to this logic, the way to solve the labyrinth is not by mapping it from within, but rather by assuming a vantage point from above looking down, providing a totalizing view from which to hold sway. Cartesian Perspectivalism was thus imbued with the potential to illuminate what was dark, to make clear what was obscure. The core ambition of the Enlightenment - the emancipation from bondage - was predicated on this potential, on the suture of lucidity and rationality, on the increasing capacity to render the world transparent.

It is difficult to overstate the profound epistemic influence this new scopic regime had on the course of Western civilization. Jay underscores its widespread dissemination and adoption through a catalogue of influential thinkers, including Voltaire, Jean-Jacques Rousseau, John Locke, David Hume, Francis Bacon, Baron de Montesquieu, Denis

\footnotetext{
${ }^{27}$ Jean le Rond d'Alembert, Preliminary Discourse to the Encyclopedia of Diderot, trans. Richard N. Schwab and Walter E. Rex (New York, 1963), 46-47, as cited in Jay, 83.
} 
Diderot, and Isaac Newton, each of which espoused a visually inflected philosophy. Voltaire, for example, in response to his rhetorical query "What is an idea?," answered "It is an image that paints itself in my brain." ${ }^{28}$ Jay also identifies the pervasiveness of a visual bias in the reign of the Sun King, Louis XIV, which was fixated with light, mirrors, and the spectacle of the royal court. More significantly, he notes the various ways that the French Revolution can be said to have privileged sight in concert with reason in pursuit of its emancipatory objectives. He highlights how the eye of providence - the all-seeing eye surrounded by rays, which had also been introduced into the Great Seal of the United States and is still on the back on the dollar bill-was incorporated into French revolutionary iconography. The cumulative evidence suggests that Cartesian Perspectivalism came to constitute a dominant feature of the epistemology spawned by the Enlightenment; knowing was now inexorably linked with seeing. The hegemony of the visual now assured, its masterful authority would continue to grow, reaching its apex in the $19^{\text {th }}$ century with the advent of those new events, forces, and institutions that have come to be defined as modernity.

For many commentators, early $19^{\text {th }}$ century modernity was the age of the eye and the most fully realized expression of the scopic regime known as Cartesian Perspectivalism. Both Jay and Crary note how vision — with the aid of new technologies like the stereoscope, the microscope, and photography—-became the dominant sense of the early modern world. In the realm of aesthetics, Jay notes the ocularcentric proclivity of the then-bourgeoning style of realism. Although it was taken up in all the arts, realism

\footnotetext{
${ }^{28}$ Voltaire, A Philosophical Dictionary, ed. and trans. Theodore Besterman (New York: Penguin Books, 1972), 236.
} 
was perhaps most famous as a literary genre, one that espoused an observational mode of fiction writing to arrive at a true reflection of reality. Authors who wrote in this mode even used visual metaphors to describe their craft. ${ }^{29}$ We can also note the codification and widespread adoption of the scientific or experimental method, a precisely defined system of inquiry based on gathering observable, empirical, and measurable evidence and rigorously subjecting this material to rational scrutiny. This method bestowed unparalleled legitimacy on the knowledge it produced.

These and other examples we could cite reinforce the claim that sight was the dominant sense of the early modern world and a critical component of that period's epistemological structure. Art and literary historian Wylie Sypher does not overstate the case when he describes the $19^{\text {th }}$ century as "among the most visual periods of Western culture, the most given to ideals of precise observation - a spectator-view shared by novelists, painters, scientists... who became 'visionary. ${ }^{9,30}$ All of this ocularcentric activity was bequeathed by the Enlightenment to modernity, which in its early stages elaborated and intensified the hypertrophy of the visual as never before. It should come as no surprise that a genre of fiction would emerge under the auspices of this epistemological order that would, in its own way, focus its thematic concerns and narrative conventions on expressing and validating this order's ocularcentric conception of knowledge.

\footnotetext{
${ }^{29}$ See note 104 in Jay, 111.

${ }^{30}$ Wylie Sypher, Literature and Technology: The Alien Vision (New York: Vintage Books, 1971), 113.
} 
A close inspection of the first detective stories clearly indicates an epistemic affinity with modernity and its coetaneous scopic regime. However, before we proceed with an examination of a specific example, I would like to provide a more general analysis of detective fiction's scopic assumptions, with particular emphasis on its relationship to Cartesian Perspectivalism. With support from the extensive scholarship on the genre, I intend to demonstrate that the causal link between sight and knowledge forged by Enlightenment forces is a constitutive thematic concern of detective fiction. As part of its basic operations, all detective stories in one way or another, either implicitly or explicitly, test the viability of this relationship. Since the causal link between the two was never as strongly conceived as during the rise of modernity, our analysis of detective fiction begins there.

Detective fiction's debt to the forces unleashed by the modernization process of the $19^{\text {th }}$ century cannot be overstated. It is difficult to imagine the development of the genre without reference to this transformative event, and indeed the strong associative link between the two is frequently noted by commentators. The most thorough account is Jon Thompson's Fiction, Crime, and Empire: Clues to Modernity and Postmodernism, a work whose stated thesis is that "fictions of crime offer myths of the experience of modernity." ${ }^{\text {31 }}$ A. E Murch and Julian Symons, two eminent scholars in the field of detective literature, both corroborate this point through their own detailed examination of

\footnotetext{
${ }^{31}$ Jon Thompson, Fiction, Crime, and Empire: Clues to Modernity and Postmodernism (Champaign: University of Illinois Press, 1993), 2.
} 
the genre's history. ${ }^{32}$ On the whole, it would seem that a distinguishing feature of the detective story is its potent capacity to mediate the experiences of a modern sensibility. Out of the constellation of developments associated with modernity, the one that had the most direct effect on detective fiction was the rising prominence of the urban centre. The modern detective story owes much to the widespread urbanization of social, cultural, and political life during this time.

There is a certain irony in the fact that, while the modern scopic regime--that evolved, superlative version of Cartesian Perspectivalism that bloomed in the $19^{\text {th }}$ century - promised unsurpassed clarity and transparency, its effects were seemingly undone by what may be described as the increasing obscurity of the modern urban landscape. Georg Simmel's classic study of the physiological effects of urban living, with its emphasis on the overly stimulated sensory perception of city-dwellers, bears witness to the disruption of normal cognitive functioning caused by the "rapid crowding of changing images, the sharp discontinuity in the grasp of a single glance, and the unexpected onrushing impressions" that dominated the urban experience. ${ }^{33}$ Cognitive disruption seemed to contribute to a more general failure in the capacity of the urban class to generate a totalizing picture of the metropolis, one that could aid in navigation and secure one's position relative to its overall design. The well documented efforts by certain municipalities to make cities more transparent and more navigable testify to the

\footnotetext{
${ }^{32}$ See A.E Murch, The Development of the Detective Novel (Port Washington: Kennikat Press, 1968) and Julian Symons, Bloody Murder: From the Detective Story to the Crime Novel: A History, $2^{\text {nd }}$ ed. (New York: Viking Penguin Inc., 1985).

${ }^{33}$ Georg Simmel, The Sociology of George Simmel, trans. and ed. Kurt H. Wolff (New York: Free Press, 1950), 410.
} 
$19^{\text {th }}$ century sense of the city as inscrutable, opaque, and obscure. ${ }^{34}$ The disorienting effects of the physical landscape of these expanding urban centres were exacerbated by their recent absorption of political power and social prestige, both of which had become centralized within the modern city's boundaries by this time; navigating the city's topography was the physical correlate to navigating its equally obscure political and social dimensions. Recalling d'Alembert's abstract description of the general system of the sciences and arts, the modern city was the labyrinth made real. Yet d'Alembert's solution for the labyrinth—to place oneself at a high vantage point from whence to perceive its totality - could not be applied to the modern metropolis since such a feat was beyond the physical, political, and social means of the common citizen.

Most scholarly accounts of detective fiction suggest that the genre trades on the uncertainty of such a scenario, on the haunting danger that accompanies navigation of the urban landscape. One scholar in particular, Richard Alewyn, uses the same metaphor as d'Alembert in his account of the genre: "The apparently so prosaic and secure everyday life of the modern Metropolis turned out to be nothing but a thin and brittle cover undermined by a labyrinth of criminal conspiracies." ${ }^{, 35}$ This sentiment finds support in Murch's claim that "there can be no doubt that [detective fiction] expresses drama, especially the drama of city life, - the crowds of strangers, the ever-present possibility of a chance encounter with crime in a train or a bus, the frightening, unexpected things 'that

\footnotetext{
${ }^{34}$ Paris, as we shall see, was typically at the forefront of such efforts.

${ }^{35}$ Richard Alwewyn, "The Origin of the Detective Novel" in The Poetics of Murder: Detective Fiction and Literary Theory, eds. Glenn W. Most and William W. Stone (New York: Harcourt Brace Jovanovich Publishers, 1983), 75.
} 
could happen to any one. ${ }^{936}$ One of the more interesting accounts is Albert D Hutter's where, in an echo of Simmel, he acknowledges the cognitive disruption caused by the urban environment, explicitly contextualizing the problem in epistemological terms: "Detectives are thus inevitably concerned with the problem of knowledge, a problem only intensified by the urban upheaval of the world in which they move, by the disorder, the multiplicity of detail, the constant impinging presence of other people, other accounts, other view points. ${ }^{37}$ However, the most poetic statement on the matter emerges from the pen of G.K Chesterton, who, as a writer of detective fiction himself, understood the genre perhaps more intimately than other scholars. In a critical study of the genre, Chesterton highlights the almost monstrous quality of the mysterious urban landscape: "The lights of the city begin to glow like innumerable goblin eyes, since they are the guardians of some secret, however crude, which the writer knows and the reader does not. Every twist of the road is like a finger pointing to it; every fantastic skyline of chimney-pots seems wildly and derisively signaling the meaning of the mystery." 38

We could say, in effect, that the detective was invented by the city. As they began cultivating their status as centres of various networks of power and influence, modern cities required a figure whose role was to map those networks, to provide a totalizing picture of its labyrinthine structure, and to make transparent its otherwise opaque nature. This role was conferred on the detective. It is the detective's clarity of vision-far above that of ordinary men and women-that grants him or her the privilege of standing as the

\footnotetext{
${ }^{36}$ Murch, 14.

${ }^{37}$ Albert D Hutter, "Dreams, Transformations, and Literature: The Implications of Detective Fiction" in Poetics of Murder, 235.

${ }^{38}$ G.K Chesterton, The Defendant (Letchwork: The Temple Press, date unknown), 159.
} 
masterful surveyor of the modern metropolis, of having the capacity to generate the totalizing perspective denied the typical urban inhabitant. Literary theorist Fredric Jameson argues for the relevance of the detective figure in precisely these terms: "Since there is no longer any privileged experience in which the whole of the social structure can be grasped, a figure must be invented who can be superimposed on the society as whole, whose routine and life pattern serve somehow to tie its separate and isolated parts together." 39 For his part, Hutter argues that detectives were necessary to "'read' a city that had grown far beyond the easy knowledge of its inhabitants. ${ }^{, 40}$ Following the general scholarship on the genre it can be said that, as a cultural figure, the detective may be considered a form of resistance to the forces at play that render the city inscrutable, forces that were beyond the ken of the ordinary urban citizen.

It is no accident that the puzzle at the heart of most detective stories concerns an act of murder. An unsolved murder - not comprehending the source of the violence or the motive for the attack - was a glaring sign denoting the limits of enlightened reason; it served a metonymic function, standing in for those unknowable aspects of the modern world, and, in particular, of the metropolis, by bringing into focus the insecurity of everyday, routine urban existence. The uncertainty that is registered by an unsolved murder has an ominous tone, portending a world without order and cohesion, an unpredictable world of chaos and danger. Everyone, each inhabitant, is put in jeopardy by an unsolved murder. To solve the murder through the application of rational deductive reasoning was to tame this menace, to pacify those fears associated with this uncertainty.

\footnotetext{
${ }^{39}$ Frederic Jameson, “On Raymond Chandler” in Poetics of Murder, 122.

${ }^{40}$ Hutter, Poetics of Murder, 235.
} 
Here we perhaps discover the reason why the supernatural is routinely dismissed as a possible cause of the crime in detective fiction. ${ }^{41}$ The supernatural exists beyond the bounds of rationality, outside a comprehensible world order. To attribute a murder to a supernatural source would do nothing to tame the anxiety of uncertainty caused by such an act. So the detective prowls the streets of the urban landscape and, in the words of one commentator, brings "comfort and a sense of security to millions of individuals" through the astute application of rational deductive reasoning.

The act of investigation we associate with detectives consists of several parts that, taken together, constitute the basic operations of cognitive deduction. Sight plays a fundamental role in this process. To begin with, a detective must physically penetrate the space of the mystery in order to expose his or her senses to the evidence. In this activity, it is the visual field that is privileged. This no doubt explains why one of the central images bound up with Sherlock Holmes in the popular imagination is the magnifying glass. Yet more than the direct ocular perception of clues, which, to be sure, is sometimes supplemented by information derived from other senses, is the Cartesian-inflected ability to tie together seemingly random fragments into a meaningful whole and then retain an image of it in his or her mind ("painted" in the brain, to quote Voltaire) for inspection. It is this particular ability that defines detectives because, unlike those around them, they are able to "see" the larger pattern represented by the perceivable evidence. In short, they make visual sense out of nonsense. We get a glimpse of this ability at the end of the

\footnotetext{
${ }^{41}$ Many detective stories feature supernatural elements for the express purpose of illustrating the efficacy of rational deductive reasoning in their demystification. See for example Sir Arthur Conan Doyle, The Hound of the Baskervilles (New York: Dodd, Mead \& Co, 1968).

${ }^{42}$ Stephen Knight, “...'some men come up...'--the Detective appears” in Poetics of Murder, 288.
} 
typical detective story when, in a convention of the genre, the detective demonstrates the deductive methods used to solve the mystery. Since the sequence of events has been clarified in the mind of the detective, but remains obscure to the other characters (perhaps even to the reader), the detective proceeds to "draw a picture," to use an accurate metaphor. Each seemingly unrelated piece of evidence is demystified by its integration with the others, woven together into one comprehensible image.

Having established in theory the basic underpinnings of the detective genre, particularly its role in mitigating the anxiety produced by the impenetrable forces of the modern city, our attention now turns to one of these urban centres, a metropolis worthy of hosting what most scholars agree is the very first fictional detective. Paris was, to use Walter Benjamin's celebrated phrase, "the capital of the $19^{\text {th }}$ century,"43 and thus at the centre of a historical period recognized as perhaps the most inclined to ocularcentric activity. As we have already noted with the spectacle-based economy of Louis XIV's royal court and the visually-inflected iconography of the French Revolution, French culture had already been predisposed towards a visual sensibility in the Cartesian mode even before the intense fetishization of sight that accompanied early modernity. Indeed, the hypertrophy of the visual that took place in Western societies during the 19th century was perhaps nowhere as keenly expressed as in France-Paris in particular. During this period, French interest and activity in the possibilities of augmenting or supplementing the sense of sight was instrumental in the development of both photography and the cinema, as well as technical advances in other optical equipment like lenses and mirrors.

\footnotetext{
${ }^{43}$ Walter Benjamin, Charles Baudelaire: A Lyric Poet in the Era of High Capitalism, trans. Harry Zoane and Quintin Hoare (London: New Left Books, 1973), 155.
} 
Jay also highlights the transfer of the spectacle culture of the royal court of the Ancien Régime from the aristocracy to the general population with the construction of the first glass-enclosed shopping areas and department stores. At around the same time, recent advances in lithography resulted in a French-led explosion of advertising and other images in journals and newspapers. ${ }^{44}$

Yet Jay also takes pains to demonstrate how Paris itself suffered from that general opaqueness that plagued all great modern cities. In addition to its labyrinthine physical dimension—a medieval legacy—Jays states that the visual experience of early, $19^{\text {th }}$ century Paris seems to have been "overwhelming in its phantasmagoric confusion." Solutions to the growing inscrutability of Paris were predictably ocularcentric in nature. The most dramatic was likely the mass demolition and reconstruction of Paris in the latter half of the century along a more visually uncluttered ideal, a project spearheaded by the then prefect of the city, Baron Georges-Eugène Haussmann. In accordance with his grand design to modernize the capital, uncompromising rectilinear boulevards replaced the narrow, scattershot street system Haussmann inherited. To the "Haussmannization" of Paris we can add the long-term efforts for a comprehensive system of artificial illumination as perhaps the city's other central solution to the problem of its mounting inscrutability. In his comprehensive study, Disenchanted Night: The Industrialisation of Light in the Nineteenth Century, Wolfgang Shivelbusch describes the progressive perfection of street lighting of several European capitals during the $19^{\text {th }}$ century; yet it is

\footnotetext{
${ }^{44}$ Jay, 120-121.

${ }^{45}$ Ibid., 115.
} 
clear that Paris was, by far, at the forefront such efforts. ${ }^{46}$ Shivelbusch also notes that one of the central aims of Parisian officials in lighting up the city after dark-particular to Paris-was to make the city more readable for police and security officials who, scholars contend, were the real-life inspirations for fictional detectives. ${ }^{47}$ Is it any wonder that the first modern detective story featured a Frenchman as its detective-hero, and was set on the illuminated streets of Paris, despite the fact that its author was American?

With few exceptions, most historians of detective fiction locate its origin in the work of Edgar Allen Poe, who between 1841 and 1844 wrote the three short stories that both inaugurate and define the genre. One of the most comprehensive historical accounts, Murch's The Development of Detective Fiction, traces the roots of detective fiction to a handful of $18^{\text {th }}$ and early $19^{\text {th }}$ century novels, yet he is clear on the issue of where to locate the genesis of the genre. Murch asserts that it is Poe to whom "we owe the detective story as we know it today" and that with the publication of his first work "a new genre came into being with its own distinctive shape, substance and individuality." ${ }^{\text {"48 }}$ The idea that the genre emerged fully formed from the pen of Poe finds support in another historian of detective fiction, Julian Symons, who declares that "Almost every later variation in plot in the detective story can be found in the...short stories he wrote which...can be said to fit within the limits of the form." 49 Poe's work establishes the "classical" detective story later elaborated by the likes of Sir Arthur Conan Doyle and

\footnotetext{
${ }^{46}$ Wolfgang Schivelbusch, Disenchanted Night: The Industrialisation of Light in the Nineteenth Century, trans. Angela Davies, (Berkely: University of California Press, 1988).

${ }^{47}$ French detective Vidocq in particular, who as we shall see is referenced in Poe's first detective story.

${ }^{48}$ Murch, 83.

${ }^{49}$ Symons, 34-35.
} 
Agatha Christie. The manner in which Poe's stories establish the generic constituents of detective fiction is well documented and does not need to be reiterated here. However, few accounts detail that particular aspect of Poe's detective stories that concerns us: the manner in which they advocate for the adoption of a Cartesian perspective. Accordingly, our attention now turns to The Murders in the Rue Morgue-the first detective story ever written —and how, through plotting and thematic development, it validates the notion that keen observation is fundamental to the acquisition of knowledge.

The Murders in the Rue Morgue is an 1841 short story by Poe that faithfully adheres to the framework of detective fiction we have established. Its setting is Paris and its hero is C. Auguste Dupin, an individual of superlative observing and reasoning skills. Dupin is not only cognitively adjusted to the metropolis, but seems convinced that its visual cacophony actually enhances his intellectual faculties. In a sentiment that would be alien to Simmel's disoriented urban traveler, Dupin freely admits to "seeking, amid the wild lights and shadows of the populous city, that infinity of mental excitement which quiet observation can afford. ${ }^{, 50}$ Here is an individual who thrives in the face of that "phantasmagoric confusion" of early modern Paris Jay describes, attuned to its sensations, able to perceive its underlying patterns. As both Murch and Symons note, Dupin's powers of observation and rationalization are so great that our access as readers to the machinations of these powers must be mediated through his companion, the nameless narrator, an individual of only common ability. Both scholars contend that this dramatic strategy was meant to emphasize the almost superhuman cognitive capacities of

${ }^{50}$ Edgar Allen Poe, Selected Tales, ed. David Van Leer (Oxford: Oxford University Press, 1998), 96. 
the detective by denying any direct contact with his thinking process. Dupin's powers, such a design suggests, are so great as to be unrepresentable. This particular strategy was taken up and perfected by Poe's successor, Sir Arthur Conan Doyle, whose detectivehero Sherlock Holmes relies on his celebrated assistant Dr. Watson to relate his impressive feats of deduction.

The Murders in the Rue Morgue, in fact, begins with a short treatise by the narrator exalting analysis, reflection, reasoning, and other related mental activities that Poe collected under the term ratiocination. ${ }^{51}$ Even in this opening section, one is struck by the degree to which ratiocination is heavily reliant on visuality. The narrator, in distinguishing between levels of observational aptitude, states that "the difference in the extent of the information obtained is not so much in the validity of inference as in the quality of the observation. The necessary knowledge is that of what to observe. ${ }^{, 52}$ In this passage, deductive reasoning is actually reduced in importance relative to vision in regards to acquiring knowledge. What is also implied in this statement is that observation is not a passive act, but an active one that can be executed with different levels of ability, that different individuals can be more or less endowed with relative observational skills. This passage also serves as the moral lesson of the story, having been discerned by the narrator in light of the events that he is about to relate retrospectively. The purpose of his tale is thus to demonstrate this lesson in practice via its application in solving a seemingly intractable mystery.

\footnotetext{
${ }^{51}$ Though it bears all the hallmarks of one, the narrator actually claims that this opening section is not a treatise. Poe may have included the disclaimer ironically.

${ }^{52}$ Ibid., italics in original, 93.
} 
At first glance the details of the murder at the centre of the story defy explication. Madame L'Espanaye and her daughter are discovered brutally murdered and, with the entrances and exits to the apartment seemingly secure, the assailants appear to have vanished into thin air. Both bodies have been subjected to a variety of horrific violence, the gruesome and bizarre nature of which only adds to the mystification of the crime. The police are confounded, unable to come up with any reasonable explanation for the scene they witness. A succession of newspaper reports details their lack of progress in the case, indicating that the premises had been searched and re-searched but to no avail. Dupin, disparaging the "shell of an examination",53 conducted by the police, decides to undertake the task of solving the mystery himself. With the narrator in tow, he declares that the first order of business is to go and see the premises with their "own eyes." various experts on the police force and the narrator himself search the apartment, it is not until Dupin subjects the crime scene to his own penetrating scrutiny that the mystery is finally unraveled.

Dupin's claim to have solved the crime at first astonishes his companion-after all, they examined the crime scene together, yet, of the two, only Dupin arrived at a solution. How did Dupin triumph where both the narrator and the police failed? The answer would seem to lie in their relative abilities for astute observation. Dupin says it plainly to his companion, "You have observed nothing distinctive. Yet there was something to be observed. ${ }^{, 55}$ It is Dupin who determines that the apartment must not

\footnotetext{
${ }^{53}$ Ibid., 105.

${ }^{54}$ Ibid., 107

${ }^{55}$ Ibid., 108.
} 
have been as secure as initially presumed, a supposition confirmed upon his discovery of a concealed spring in the window and the fake nail embedded in the frame, mistakenly taken as real by the police investigators. The "cursory examination" of the courtyard conducted by these same officials also failed to disclose that the outdoor shutters of the pertinent window could potentially swing out near enough to the lightning rod to serve as a means of entering and exiting the apartment. ${ }^{56}$ Dupin's greater acumen perceives this possibility which can reasonably explain the perpetrators' entrance and escape. By piecing together these visually-attained clues, Dupin is able to disentangle what the others cannot. He is able to weave together a coherent picture out of the apparent disorder due to his ability to see what others miss, and then correctly process the ensuing perceptual information into a coherent whole. Dupin is justified in dismissing the flawed perceptions of the police_-"not trusting their [the police's] eyes, I examined with my own" ${ }^{\text {} 57}$ - because they exposed their ineptness by failing to process cognitively what was explicitly in their visual field.

Dupin's elaborations on the subject reveal that, even though knowledge passes through the visual field, attentive looking is not enough. For Dupin, the imperative is to adopt a particular mode of observation, one he describes by way of example. Dupin invokes a historical detective - the infamous Vidocq ${ }^{58}$ - whose success, according to Dupin, was due solely to being a "good guesser, and a persevering man."59 Vidocq's failing was that he functioned within a mode of observation that was too literal. Of his

\footnotetext{
56 Ibid., 112.

${ }^{57}$ Ibid., italics in original, 110.

${ }^{58}$ Both Symons and Murch argue that Dupin was actually modelled on this historical individual.

${ }^{59}$ Poe, 105.
} 
working methods, Dupin states that Vidocq "erred continually by the very intensity of his investigations," and that he "impaired his vision by holding the object too close." ${ }^{.60}$ As a result, the capacity to envision the larger picture was lost: Vidocq "might see, perhaps, one or two points with unusual clearness, but in so doing he necessarily lost sight of the matter as a whole. ${ }^{, 61}$ According to Dupin, even looking too closely can hamper the cognitive aspect of deduction since interrelating perceptual information is a crucial component of the deductive process. The notion that a gaze too deep risks clouding our perceptual judgment is given clear articulation by Dupin: "By undue profundity we perplex and enfeeble thought; and it is possible to make even Venus herself vanish from the firmament by a scrutiny too sustained, too concentrated, or too direct. ${ }^{, 62}$ Such a mode of observation strays too far from the Cartesian ideal, embodied by Dupin, which realizes its power through an appreciable distance between observer and observed. Taken together we can detect, in these passages, the same solution d'Alembert proposed for the labyrinth: to place oneself at a high vantage point from which to perceive the totality. The police in Poe's story do not conform to this observational ideal, which results in their failure to solve the mystery. Such a mystery can only be solved by someone like Dupin-someone, that is, who shrewdly adopts Cartesian Perspectivalism as his mode of observation.

One can read the methods relied upon by the classical detective, including adoption of a Cartesian perspective, as corresponding to those used in the scientific

\footnotetext{
${ }^{60} \mathrm{Ibid}$.

${ }^{61}$ Ibid.

${ }^{62}$ Ibid., 106.
} 
method. Both resort to the cold logic of empirical evidence in their pursuit of knowledge. That the methods overlap in this way is not surprising considering how they each originate from Enlightenment principles that link vision and reason. Both the classical detective and the positivist scientist of the $19^{\text {th }}$ century were in the business of establishing inviolable facts in a struggle to impose uncompromising order over the apparent disorder of reality. Moreover, in each case the process used was based solely on the precision afforded by the lucid, rational mind, consciously divorced from the more disordered dimensions of human sensibilities. The affinity between the two is expressed in the following passage of Conan Doyle's $A$ Study in Scarlet, in which Sherlock Holmes admonishes Dr. Watson for the way he (Dr. Watson) dramatizes their adventures together in print:

Detection is, or ought to be, an exact science and should be treated in the same cold and unemotional manner. You have attempted to tinge it with romanticism, which produces much the same effect as if you worked a love story or an elopement into the fifth proposition of Euclid... The only point in the case which deserved mention was the curious analytical reasoning from effects to causes by which I succeeded in unraveling it. ${ }^{63}$

Euclid's mathematical formulas, which were instrumental in the technical achievement of linear perspective, are here invoked by perhaps the most famous classical detective of all as the embodiment of a rational ideal.

The emergence of detective fiction in the $19^{\text {th }}$ century-during the most "visual periods of Western culture," the most given to "ideals of precise observation"-realized the definitive narrative form of Cartesian Perspectivalism. That scopic regime, which forged such a robust link between seeing and knowing, was brought to its logical

\footnotetext{
${ }^{63}$ Sir Arthur Conan Doyle, A Study in Scarlet (London: Wordsworth Editions, 2000), 110.
} 
conclusion in fictional, dramatic terms upon the publication of Poe's first tale of ratiocination. Though I have focused only on this one particular detective story, I would like to stress its status as the formative model for later practitioners of the genre. The classical formula developed and showcased in The Murders in the Rue Morgue and its two sequels was fully embraced by Poe's immediate successors, most famously Conan Doyle with his Sherlock Holmes stories, but also Agatha Christie, Dorothy L. Sayers, G.K. Chesterton, and S.S. Van Dine, among others. In each case, their detective stories serve as validation of Cartesian Perspectivalism, and never question the premise that complete knowledge can be attained by those able to wield its power. The detective-hero model these authors constructed has since been labeled the "Great Detective.",64 However, as we shall see, the privileged status of this scopic regime came under increasing attack in the late $19^{\text {th }}$ and early $20^{\text {th }}$ century. As faith in its efficacy eroded, as it became subject to critique in a variety of forms, Cartesian Perspectivalism came under siege. How the hardboiled fiction of Dashiell Hammett and Raymond Chandler emerged out of these developments will be the focus of the next chapter.

${ }^{64}$ This is a general term adopted by detective fiction scholars, notably Symons and Murch. 


\section{The Dim Glow of Chandler's Mean Streets}

The Great Detective was omniscient, and believed in the supreme power of reason. The hardboiled dick moved instinctively, was as fallible as the next man, and put faith in his gun. ${ }^{65}$

It bears repeating that, despite the long-standing success of Cartesian Perspectivalism, scopic regimes are never static; their form at any given time is contingent on a variety of variable forces. In light of detective fiction's considerable indebtedness to the scopic field in which it first blossomed, it should come as no surprise that subsequent modifications in the visual order would force, in an adaptive way, corresponding variations in the genre. This chapter will examine the first major update of the detective genre, from the classical model of Edgar Allen Poe to the hardboiled variety of Dashiell Hammett and Raymond Chandler, specifically within the context of an increasingly unstable scopic regime. In relation to our inquiry, two salient distinctions between the two will be examined. The first is that hardboiled detectives do not stand apart from the world they investigate, as do their Great Detective counterparts, but are instead woven directly into its very fabric. The second is the hardboiled genre's introduction of uncertainty into the structure of the detective story. I intend to illustrate how these distinctions in hardboiled fiction arose in concert with a disruption to the hegemony of the Cartesian ideal.

${ }^{65}$ Symons, 124. 
Though there were always counter-trends against the ocularcentric bias of the dominant epistemological order, ${ }^{66}$ Jay states that "it was only during the waning years of the 19th century that a concerted challenge to the hegemony of the visual was successfully launched. ${ }^{, 67}$ At the forefront of this challenge was photography, a technology and visual medium whose arrival in the mid- $19^{\text {th }}$ century would, counterintuitively, contribute to the rise of an anti-ocular movement.

Photography, with its exacting replication of perspectival vision, was initially taken as validation of that vaunted scopic regime Cartesian Perspectivalism. Here was a technology that directly reproduced, in a manner far more accurate than painting, the framed, distant, disincarnated viewpoint so esteemed since the time of Descartes. In fact, it was not long after photography's initial invention that it was used to take aerial pictures. Frenchman Nadar was the first to take photographs from the heights of a hot-air balloon, and his subject, not coincidentally, was almost exclusively the city of Paris and its urban sprawl. In many ways, aerial photographs of Paris can be considered the most perfect realization up to that moment of the highly exalted Cartesian mode of observation: the labyrinth was literally seen from above. Moreover, by virtue of what was eventually termed its indexical nature, photography also seemed to have the capacity to reveal the objective truth of reality - the implied teleological goal of perspectival vision. ${ }^{68}$ This power eluded all other representational mediums or devices up to photography's arrival. Yet, ironically, the uncertainty over vision that was to arise

\footnotetext{
${ }^{66} \mathrm{Jay}$, for example, cites the Baroque movement.

${ }^{67}$ Jay, 187.

${ }^{68}$ The term indexicality was coined by C.S Pierce, who was also the first to apply it to photography. See his "Logic as Semiotic: The Theory of Signs," in The Philosophy of Peirce: Selected Writings, J. Buchler ed. (London, 1940), pp 98-119.
} 
decades later, and the explicitly anti-ocular strand of postmodernism that was to flourish post-1960s, can trace at least part of its origin to the scopic invention of the $19^{\text {th }}$ century that initially raised Cartesian Perspectivalism to new heights.

Jay identifies several ways that photography courted skepticism of perspectival vision. The first is that photography, despite its highly accurate reproduction of reality, only imperfectly replicated natural vision. When the abstract ideal of Cartesian sight was finally demonstrated in photographic form, the results did not match the perceptual impressions experienced by embodied eyes. As a result, in both the aesthetic and discursive realms, focus soon shifted from the ideal to the material, from an abstract vantage point to the physical operations of the seeing eye. The second concerns the photograph's ambiguous relationship to "reality" or "objective truth," the precise nature of which has yet to be determined despite decades of vigorous theoretical debate on the issue. ${ }^{69}$ On the whole, the extensive discourse on the medium suggests there exists a disjunction between the objective truth the photograph promises and the inherent manipulation involved in its production. ${ }^{70}$ Following from this point is the third and perhaps most significant way that photography disrupted the observational ideal espoused by Cartesian Perspectivalism: as early as 1855 it was revealed that photographs could be retouched or otherwise altered. The core ambition of Cartesian Perspectivalism-to supply mastery of the external world by visual means - was undermined by this aspect of photography. Thus it was clear from the beginning that photography had a paradoxical

\footnotetext{
${ }^{69}$ See: Susan Sontag, On Photography (New York: Anchor Books Doubleday), 1977. She does an admirable job of delineating photography's complex and ambiguous nature.

${ }^{70}$ At one extreme end of this debate is film theorist André Bazin, who claimed that there was an ontological identity between image and model. See "The Ontology of the Photographic Image" in his What is Cinema? (Berkley and Los Angeles: University of California Press), 1967.
} 
character: while its capacity to render an accurate recording of nature was unrivaled, one could never gauge the trustworthiness of any particular recording, nor its particular relationship to what it depicted. Neither theory nor practice has yet to resolve the tension between these discordant qualities of the medium. Ultimately, the scopic authority that photography seemingly possessed proved illusory, and the distrust of the visual evidence it was thought to supply was to translate into a distrust of visuality more generally.

Photography also helped usher in the interrogation of the received visual order in another way. Painting, which had historically been the aesthetic standard bearer of Cartesian Perspectivalism, was all of a sudden displaced from that position, trumped by a medium that was immeasurably more capable. Until photography, perspective painting had been the sole method to actualize, however crudely, the "window on the world" vantage point as theorized by Descartes, reaching its zenith in this campaign with the realistic illusionism of the trompe-l'œil technique. With this representational burden lifted, painting was free to explore alternative visual practices—or, more pessimistically, it was left with no choice but to do so. Painter Paul Delaroche made this now-infamous statement, uttered just as photography was made public for the first time: "From this day on, painting is dead." ${ }^{\text {71 }}$ Although proven wrong, Delaroche's comment testifies to feelings of uncertainty over the future viability of painting in light of photography's invention. Art historian H.W. Janson notes that because photography "established a standard of representational accuracy that no hand-made image could hope to

\footnotetext{
${ }^{71}$ Paul Delaroche, as quoted in Jay, 136.
} 
rival...painting needed to be rescued from competition." ${ }^{\text {72 }}$ Janson's comment is taken from his introductory remarks to an examination of a movement in painting whose advent, he claims, "rescued" the medium of painting, and, in the process, would overturn the perspective paradigm once and for all.

Though it may be a stretch to claim that Impressionism saved painting, it is clear that this new visual practice, and those that directly followed, brought new vigor and purpose to a medium that had been cast partly adrift. One of the ways it did so-perhaps the most crucial—was by relocating the focus of the work of art from narratives and objects - the traditional subjects of painting - to the experience of seeing itself. In place of the visual depth of perspective, the Impressionists, as Jay states, "sought to reproduce the experience of light and colour on the retinas of the eyes. ${ }^{, 73}$ The result was that instead of looking through the painting onto a theatricalized scene placed in an idealized, geometrically rigid space on the other side of the "window" as seen from afar, one was forced to look at the painting, at the individual brushstrokes, blurred forms, and súbjective colour palettes, and to perceive the two dimensional flatness of the canvas. Thus content gave way to form, or, put another way, the content of a work of art-its actual subject-increasingly became its form. The visual possibilities that such a shift suggests would be thoroughly explored in due course, resulting in the high modernist formalism of the early to mid $20^{\text {th }}$ century. The arrival of these aesthetic movementspost-Impressionism, Cubism, Futurism, Vorticism, and, eventually, pure formal abstraction -indicates this was a time of intense interrogation of the Cartesian visual

\footnotetext{
${ }^{72}$ H.W. Janson, The History of Art, $4^{\text {th }}$ ed., (New York: Prentice Hall Inc.), 665.

${ }^{73}$ Jay, 154.
} 
ideal. However, it is important to recognize that the power of the visual did not abate during this time; although it was assuredly on the wane, it continued to hold onto its position of dominance. Yet the sudden and widespread exploration of alternative visual practices broke the hegemony of the scopic regime of Cartesian Perspectivalism. Lacking the common reference point provided by a dominant model, what emerged in the visual register is what art historian T.J. Clark refers to as "doubt" " and Jay as an "aesthetics of uncertainty. ${ }^{, 75}$

Coupled with this aesthetic turn away from perspective was a growing chorus of philosophers and other thinkers actively speaking out against the hegemony of the visual, adding a potent discursive dimension to the growing aesthetic unease over the dominant scopic regime. Although he provides evidence of an anti-ocular bias as early as Nietzsche, it is Henri Bergson to whom Jay grants the privilege of standing as "the first modern philosopher anywhere to dispute the nobility of sight," certainly the first to have any lasting impact. ${ }^{76}$ Overtly directed against the hypertrophied role of vision, with its atemporal, frozen spatialization, Bergson sought to restore in importance the sensation of experienced time, or durée. Jay also notes philosopher Martin Heiddeger's rigorous denunciation of the Western world's reliance on a visually fortified epistemology. In adding momentum to a burgeoning anti-ocular movement, Heidegger spoke derisively of the Cartesian tradition of "enframing" and of "the conquest of the world as picture,"

\footnotetext{
${ }^{74}$ T.J. Clark, The Painting of Modern Life: Manet and His Followers (Princeton: Princeton University Press, 1984), 12.

${ }^{75}$ Jay, 159.

${ }^{76}$ Jay, 186.
} 
which was to him the highly regrettable "fundamental event of the modern age."77 Another thinker Jay cites who demonstrated an anti-ocular tendency in the early part of the $20^{\text {th }}$ century is George Bataille, who can be read, much like other dissenters, as seeking to destroy the disincarnated distance between observer and observed, and relocate consciousness into lived corporeal existence.

To be sure, this movement lacked coherency and direction. Whatever discernable form it took can be attributable to a common desire to tear down the received order, as opposed to a unified vision for the future. Although there were alternatives proposed to both the prevailing scopic regime and, more radically, to the whole of the epistemological system, none would coalesce into a dominant force until, arguably, the advent of postmodernism. However, what can be stated with confidence is that the work of these thinkers reinforces the notion that this was a time of scopic uncertainty, that, although there were obvious transformations afoot in the visual order, their implications and consequences remained unclear.

The early $20^{\text {th }}$ century thus saw the first real challenge to Cartesian Perspectivalism. Assailed on a variety of fronts, this scopic regime, which had dominated Western sensibilities for centuries, had its privileged status disputed by a surge of untested visual orders. Although ultimately comprised of a heterogeneous mix, a new visuality emerged whose unifying principle rested on a rejection of perspective and its window on the world in favour of a sensory experience that was more thoughtfully enmeshed in the perceptual field. The ideal gaze of Descartes-disincarnated and

\footnotetext{
${ }^{77}$ Martin Heidegger, "The Age of the World as Picture," in The Question Concerning Technology and Other Essays (New York: Harper \& Row, 1977), 134, as cited in Jay 272.
} 
distant-ceded some its vaunted authority to the implicated viewpoint of an embodied perceiver. Alternative visual practices flourished but without the steadying guidance of a dominant model all were imbued with a degree of uncertainty. Thoughts turned away from the long held goal of achieving visual mastery of the objective world, the feasibility of which was, in any case, increasingly cast into doubt. Detective fiction, heavily indebted to the Cartesian mode of observation for its constitution, did not escape the effects of this creeping scopic uncertainty. A new breed of detective story emerged within this climate that in fundamental ways registered this doubt. Refashioned with the capacity to handle the ambiguity, complexity, and contradictions of an unstable scopic regime, hardboiled fiction was a calculated departure from the model detective story as designed by Poe and faithfully imitated by his immediate successors. Our attention now turns to the hardboiled tradition of detective fiction, and the ways in which it can be read as a reaction to the state of flux brought about by scopic uncertainty.

If we consider detective stories in relation to particular observational modes, this genre of fiction did not alter in configuration in any significant way until the arrival of the hardboiled variety in the mid 1920s. Sir Arthur Conan Doyle, Agatha Christie, Dorothy L. Sayers, G.K. Chesterton, and slew of more minor authors, all followed Poe's lead in writing detective stories that both expressed and validated the Cartesian visual ideal that so thoroughly linked seeing with knowing. Although some of Poe's acolytes continued to produce stories based on his classical model all through this period and beyond, that 
brand of detective fiction was decidedly and irrevocably overshadowed by its hardboiled scion. $^{78}$

It is fair to say that, historically, the two most celebrated practitioners of this particular form of detective fiction have been Dashiell Hammett and Raymond Chandler. ${ }^{79}$ More importantly, although Chinatown can be considered a composite of the work of several different hardboiled authors, the work of these two and the detectiveheroes they invented - Sam Spade and Philip Marlowe - specifically come to the fore as the primary reference points not only for this film, but for most hardboiled films then and since. The detective novels of these two authors and the early filmic adaptations thereof established an enduring legacy that Chinatown and other 1970s detective films like The Long Goodbye, Klute (Alan J. Pakula, 1971) and, later, Blade Runner (Ridley Scott, 1982) consciously mined for character, plot, structure, style, and theme. In fact, more contemporary hardboiled films like Kiss Kiss Bang Bang and Brick, as well as several recent Coen Brothers' films also overtly reference the work of Hammett and Chandler, as opposed to any of their contemporaries. ${ }^{80}$ For these reasons, my analysis will be limited to their detective novels and the resultant film adaptations-those texts that had the greatest impact on Chinatown. However, in order to supply a proper foundation for our

\footnotetext{
${ }^{78}$ Particularly Agatha Christie, who continued to write these kind of detective stories right up until her death in 1976.

${ }^{79}$ Other notable hardboiled authors include Ross MacDonald, James M. Cain and Jim Thompson, although they are not quite as celebrated as the other two, and in any case their work proved less instrumental in shaping Chinatown.

${ }^{80}$ Indirect adaptations of the work of Dashiell Hammett and Raymond Chandler can be found in Miller's Crossing (1990) and The Big Lebowski (1998) respectively, but the influence of these two authors in the work of the Coen Brothers can also be felt in Blood Simple (1985) and The Man Who Wasn't There (2001).
} 
analysis of these primary texts, a more general examination of the hardboiled genre is required.

It is important to emphasize that hardboiled fiction did not so much refute the Cartesian ideal as interrogate its assumptions. In fact, much of the Poe model remains intact in these stories. In particular, we can cite two significant continuities between them, although, as will be illustrated, it is precisely the subtle mutations within these continuities that register a new observational mode and a new kind of detective story. As for the first of these continuities, hardboiled detectives of this period were as capable of navigating the modern metropolis as their Great Detective counterparts, and certainly more so than any other character in the stories that featured them. They, too, thrived in the delirious sensory excesses of the urban centre and were able to traverse the various dimensions of its landscape - physical, social, political —with a high degree of natural competence. As for the second continuity, the original hardboiled sleuths were the equal of their predecessors in achieving the desired objective of any fictional detective, namely, the solving of the murders at the heart of the mysteries they investigate. No hardboiled detective of this period is a failure in his chosen profession. Each has recourse to impressive cognitive powers in fulfilling that all-important function of the fictional detective - Great or otherwise - which is to provide a coherent picture out of what first appearances dictate are incomprehensible fragments. However, in parsing these continuities more thoroughly, it is revealed that even within these shared attributes a divergence exists in which hardboiled fiction severely undermines the Cartesian visual ideal. 
On the first point, although hardboiled detectives are master navigators of the urban environment, they differ from their Great Detective counterparts by the vantage point they assume. Whereas C. Auguste Dupin and Sherlock Holmes heed d'Alembert's advice and gaze down on the labyrinth from above to perceive its totality, Sam Spade and Philip Marlowe view the labyrinth from within and discern its pattern though direct engagement. Dupin might visit the actual scene of the crime, as he does in The Murders in the Rue Morgue, in order to apply his own superior observational skills to the situation and, as with all detectives, he may even confront the murderer personally at the decisive moment, but his relationship to the proceedings is distant and impersonal; in every way that counts, Dupin and his Great Detective brethren are bystanders to the events that unfold before them. Conversely, hardboiled detectives force the outlines of the mystery they investigate to be revealed by consciously entangling themselves in its web. In the process, they implicate themselves not just intellectually, but physically and emotionally as well.

Chandler himself acknowledged this difference in his essay "The Simple Art of Murder. ${ }^{, 81}$ Written chiefly as a prescriptive formula for hardboiled fiction, this essay presents a comparative contrast between it and the classical variety, elevating the former while disparaging the latter. The essence of Chandler's argument against the classical model is that it is too unreal and artificial, its purpose geared excessively towards cold logic and deduction and not enough towards a more thoughtful consideration of the actual operations of criminal or investigative activity. In his words, they are "too contrived, and

\footnotetext{
${ }^{81}$ Raymond Chandler, "The Simple Art of Murder," Atlantic Monthly December, 1944, 53-59.
} 
too little aware of what goes on in the world." ${ }^{, 82} \mathrm{He}$ argues that this defect in classical detective fiction is absent in the work of Hammett who "gave murder back to the people who commit it for reasons, not just to provide a corpse. ${ }^{, 83}$ Chandler approves of Hammett's innovations because they connect his stories with the real world in a way that classical detective fiction does not; the latter's heavy reliance on the formal puzzlesolving aspect of the genre renders them too abstract. In a celebrated passage, Chandler offers his corrective recipe, which, following Hammett, rests in creating a detective figure who is deliberately built to walk down the "mean streets" he investigates, but "who is not himself mean, who is neither tarnished nor afraid." ${ }^{" 84}$ This prescriptive formula, which was generally adopted by practitioners of the genre as a whole, articulates a desire for a new kind of detective, one whose gaze originates from within the world rather than from outside it. The difficulty, as expressed by Chandler, is to keep mindful of noble purpose despite such close contact with corrupting forces. Plainly, this new breed of detective is not intended to function as a bystander.

If we recast these comments by Chandler in light of the framework I have developed, they translate into a desire to move away from that disincarnated vantage point stressed by a perspectival visual mode and towards an immersed, engaged viewpoint, one which embeds the perceiver more directly in the scene. In many ways this reading also accounts for the high volume of sex and violence that routinely permeates hardboiled fiction but which is largely absent in the classical model. Being woven more

\footnotetext{
${ }^{82}$ lbid., 56.

${ }^{83}$ Ibid., 58.

${ }^{84}$ Ibid., 59.
} 
directly into the world he investigates renders the hardboiled detective a decidedly more corporeal being — physical, sexual—and less a strictly mental one as is the case with his predecessor. The Great Detectives - Dupin, Sherlock Holmes, Hercule Poirot, Philo Vance, Miss Marple, Father Brown —are typically presented as asexual and decidedly without brawn since the physicality of both sex and violence would pollute the purity of the intellectual pursuit of puzzle-solving. Mind and body, which in the Great Detective had been subject to a Cartesian split, were largely unified in the hardboiled detective, leading to a more violent and prurient narrative form.

Of the second continuity that extends from the Great Detective to the hardboiled one-superlative mental powers - we again find that a more thorough analysis reveals a crucial divergence, one that indicates a retreat from a strict adherence to Cartesian Perspectivalism. Like his predecessor, the hardboiled detective has access to formidable cognitive abilities that are relied upon to solve the mystery. Yet his cognitive machinations are not so complex or profound that we, as readers, require a mediating figure to provide us with access. There is no character type in the hardboiled model that fulfills the Dr. Watson function, no narrating associate relating the detective's unimaginable mental exploits. Whereas the Great Detectives are endowed with superhuman cognitive gifts, hardboiled sleuths are granted abilities of a more ordinary caliber. Indeed, in his prescriptive model Chandler advocates for a type of detective in just these terms, describing his ideal as a "common man." He explains that the detective must be a common man "or he could not go among common people. ${ }^{, 85}$ Here again

${ }^{85}$ Ibid. 
Chandler betrays an implicit desire to bridge the Cartesian divide between observer and observed that structures the classical detective story. However, the acknowledged price to be paid for such a modification to the genre is a detective with more ordinary cognitive abilities. Although it is not explicitly expressed in this way, there is the sense that Chandler, and by extension the hardboiled genre as a whole, unconsciously recognizes the naivety of attempting to actualize the Cartesian ideal, that to do so requires a figure who is implausibly superhuman, a figure who can exist only in the abstract. In contrast to his predecessor, a hardboiled detective is designed to be imperfect, but also, and as a result, more "common."

With these general features of the genre in mind, I would like to examine specific hardboiled texts, ones that can be said to have had a direct impact on Chinatown. The texts I will examine fall into two groupings. The first comprises both the novel The Maltese Falcon by Hammett and its 1941 film version by John Huston, which faithfully adapts the novel. The second comprises the Philip Marlowe novels by Chandler and the 1946 film adaptation of the first of these, The Big Sleep by Howard Hawks. There are several reasons for this selection. The most important is, as stated, their direct bearing on Chinatown. These groupings also exemplify the genre more precisely than other works in the hardboiled tradition. A third reason is that the two detectives at the centre of each grouping-Sam Spade and Philip Marlowe, respectively - were cinematically immortalized by the same actor, Humphrey Bogart. His personification of these characters in the film versions of The Maltese Falcon and The Big Sleep forever fixed 
them in the popular imagination, thus making it difficult to extricate his imprint on future iterations of the genre, including Chinatown. Among many possible examples of this phenomenon one could cite is Jean-Luc Godard's conflation of Bogart and Marlowe in $\grave{A}$ bout de souffle (1960), an acknowledgment by the director of the indelible imbrication of actor and character.

I would also like to stress that while this analysis cannot be comprehensive given the scope of inquiry, I nonetheless intend to illustrate, via certain narrative details, the way in which hardboiled fiction registers the epistemological uncertainty brought about by an unfixed scopic regime, and how the causal relationship between seeing and knowing that so deeply informed classical detective fiction is interrogated in its hardboiled counterpart. Before we line up Hammett in our sights, our attention turns first to the mean, dimly lit streets in Chandler's work.

Chandler's output included several, sometimes lengthy novels. Yet the task of incorporating all this material into our inquiry is simplified by the fact that these novels are serial in nature; they all comprise a coherent, unified fictional world that features the same detective hero-Philip Marlowe-throughout. Even the passage of time between them is considered, indicated via an acknowledgement of the gradual aging of the detective. Although there is some evolution in style and thematic interests over the course of his career, there is nothing that one might describe as a decisive break from one work to the next. One constant in particular that runs throughout his hardboiled output is that each novel exhibits a palpable measure of ambiguity and uncertainty. 
His first novel, The Big Sleep, already finds Chandler consciously moving away from the classical detective model and towards the model he prescribes in "The Simple Art of Murder." In contrast to the Great Detective, Marlowe has only a plausible capacity for astute observation and rationalization and, as a result, his investigations rarely reveal a complete picture. More frequently, portions remain unresolved. Consider the initial assignment given him by his client, General Sternwood. The General has been sent promissory notes by underworld figure Arthur Geiger. The notes-gambling debts owed Geiger by the General's daughter Carmen—are supposed to be honoured by the General. Marlowe's job is to determine Geiger's motives - that is, whether the General is being blackmailed, as he suspects, or whether the notes are valid. However, before Marlowe can talk to him, Geiger turns up murdered. From there the plot proceeds along its winding path until, near the end, Marlowe finds himself back with the General who is asking him to explain some of his unorthodox methods. Marlowe's responses regarding specific actions he has taken do not completely satisfy the General because, as Marlowe confesses, he frequently relies on "hunches." Pressed some more, Marlowe acts to dispel the notion of a detective as a machine of cold, unadulterated calculation by admitting that some elements of the case, particularly those that pertain to his initial assignment, elude his cognitive grasp: "Geiger's approach puzzled me and still does. I'm not Sherlock Holmes or Philo Vance. I don't expect to go over ground the police have covered and pick up a broken pen point and build a case from it." ${ }^{, 86}$ Because he does not possess the supreme cognitive skills of a Sherlock Holmes, Marlowe never does fully deduce

\footnotetext{
${ }^{86}$ Chandler, "The Big Sleep" in Raymond Chandler: Four Complete Philip Marlowe Novels (New York: Avnel Books, 1964), 143.
} 
Geiger's motives and methods; the image that has painted itself onto Marlowe's brain is incomplete. What this passage indicates is that the absolute logic of the Great Detective, derived from a distant and disincarnated perspective, has given way to the more vague intuition of the scopically-embedded hardboiled sleuth.

The episode with Geiger is one of several unresolved mysteries that litter the narrative of The Big Sleep. One of these conundrums even stumped the author himself. The producers of the film version were having difficulty adapting the convoluted plot, and they brought to Chandler's attention a death in the novel they could not explain and whose cause-suicide or murder-they could not determine. When confronted by this puzzling plot point, Chandler himself was shocked to discover that he himself did not know how or why the character dies. ${ }^{87}$ The novel is consistently impenetrable in this fashion and, in the end, neither reader nor detective (nor author) obtains a fully inclusive and coherent picture of the events as they happened. Though justice is served, it is an incomplete justice, itself derived from an incomplete demystification of the mystery. The Big Sleep is exemplary of the way uncertainty is structured into each of Chandler's novels.

Subsequent detective stories by Chandler follow the path charted by The Big Sleep and incorporate these qualities into their very structure, cementing the philosophical gap between his type of detective fiction and its classical predecessor. For example, in The High Window the murderers, though discovered, are not even brought to

\footnotetext{
${ }^{87}$ Raymond Chandler to Jamie Hamilton, 21 March 1949. The Raymond Chandler Papers, Atlantic Monthly Press, 2000, page 105.
} 
justice, suggesting the potential futility of the investigative act. ${ }^{88}$ In The Long Goodbye, the Chandler novel which perhaps meditates most profoundly on the consequences of an embedded viewpoint, Marlowe has entangled himself so deeply and personally into a web of mystery that he palpably suffers from its effects. The loss of a dear friendship in that story is the price he pays for not maintaining a cool, cerebral distance to the enveloping mystery. ${ }^{89}$ As with The Big Sleep, the remaining Chandler novels also exhibit an occasional tendency to stage puzzles that prove too intractable for the hardboiled detective-hero to solve, a scenario outside the generic boundaries of the classical detective story.

Detective fiction scholar William W. Stowe suggests that one way of understanding the mutation from classical to hardboiled detective fiction is as a shift away from semiotics as an organizing principle in the former and towards a model based on hermeneutics in the latter- "away from the solution of 'mysteries' toward the philosophical understanding of mystery. ${ }^{, 90}$ The implications for such a shift are judiciously explored in the work of Chandler, resulting in a type of detective story that distinguishes itself from the classical model by acknowledging the limitations of the Cartesian ideal. Stowe's conclusion offers the most lucid statement on the intrinsic complexity, uncertainty and ambiguity that permeate the work of Chandler and which qualities are lacking in the classical detective story: "Doyle's readers and the readers of

\footnotetext{
${ }^{88}$ Chandler, "The High Window" in Raymond Chandler: Four Complete Philip Marlowe Novels (New York: Avnel Books, 1964), 143.

${ }^{89}$ Chandler, "The Long Goodbye" in Raymond Chandler: Four Complete Philip Marlowe Novels (New York: Avnel Books, 1964), 143.

${ }^{90}$ William W. Stowe, "From Semiotics to Hermeneutics: Modes of Detection in Doyle and Chandler," in The Poetics of Murder, 382.
} 
Poe are given reassuring examples of the power of human reason to make sense of the world. Chandler shows his readers just how little they learn from the results of such neat interpretation and what depths of mystery the process of interpretation can reveal." ${ }^{.91}$ Chandler did not seek to reassure with this detective stories. Instead he sought to construct a model that acknowledged the limitations of human reason. His inspiration for this project was another writer of detective fiction, Dashiell Hammett.

Hammett, perhaps even more so than Chandler, had a demonstrable interest in incorporating doubt into the detective genre. His greatest achievement in this regard is The Maltese Falcon. On the surface, this novel faithfully adheres to the basic conventions of the classical model. Detective-hero Sam Spade manages to solve the mystery of who shot and killed his partner Miles Archer, while also ensuring that murderess Brigid O'Shaughnessy is brought to justice. But Hammett incorporates several elements into his story that indicate a retreat from the uncompromising visual regime of Poe's stories. Because he assumes a vantage point less indebted to Descartes, and because he does not have the superhuman cognitive acumen of Dupin, Spade, like Marlowe, can only imperfectly construct a coherent picture out of the fragments he encounters.

By way of compensation, Spade frequently resorts to force in order to extract information directly from other characters. This is a repeated tactic used against Joel Cairo, but its most dramatic instance occurs with O'Shaughnessy in the final confrontation between her and Spade. Although he had done a formidable job of ferreting out the truth up to this point in the narrative, Spade is still unclear on certain specifics

\footnotetext{
${ }^{91}$ Stowe, 382.
} 
with respect to the murder of his partner, so he harangues O'Shaughnessy to "talk" and demands of her "What was your scheme?" The film version translates this scene visually by having Spade tower over O'Shaughnessy in an over-the-shoulder two-shot, dominating her physically while hammering her with questions. Eventually, she becomes physically pressed against the wall, cowering and turned away from Spade as he continues his unrelenting verbal barrage. Spade's more limited abilities allow him only to discern when the answers she provides to his questions do not naturally conform to known events or suspected actualities and, although he capably intuits when she lies and when she does not, the larger picture is beyond his immediate intellectual grasp and must be arrived at by force.

The tacit acknowledgment that Spade does not possess the Great Detective's extraordinary mental acuity is part of a larger sensibility in the work of Hammett, one that has been thoroughly explored by literary critic Steven Marcus. In his penetrating study of the author, Marcus makes a convincing case that, based on his literary output, Hammett was prone to see life as "inscrutable, opaque, irresponsible, and arbitrary." "92 In support of this claim, Marcus points to the nested narrative within the novel of The Maltese Falcon that Spade relates to O'Shaughnessy as they await a visitor. This story exists rather conspicuously as a self-contained parable and has no import or direct narrative connection to the rest of the novel. However, according to Marcus, its serves "as a means of entry into Hammett's vision or imagination of the world.",93

\footnotetext{
${ }^{92}$ Steven Marcus, "Dashiell Hammett," in The Poetics of Murder: Detective Fiction and Literary Theory, eds. Glen W. Most and William W. Stone (New York: Harcourt Brace Jovanovich, 1983), 200.

${ }^{93}$ Ibid., 198.
} 
The story that Spade relates concerns a man name Flitcraft. Flitcraft had gone missing and been missing for several years by the time Spade had been hired to locate him. As Spade tells it, he eventually found Flitcraft, who then attempted to explain his disappearance to Spade. It turns out that on the day of his disappearance, Flitcraft had a brush with death brought about by a falling construction beam, which had missed him only by inches. Flitcraft claimed that, up until this moment, his life had been a "clean orderly sane responsible affair" with a good job, wife and kids, but "Now a falling beam had shown him that life was fundamentally none of these things," and his reaction was to "change his life at random by simply going away." 94 The curious thing is that Flitcraft eventually settled into a new life whose pattern and structure was remarkably similar to his old life, right down to a new wife not unlike his first. In Spade's words "He adjusted himself to beams falling, and then no more of them fell, and he adjusted himself to their not falling." $" 95$

It is this particular aspect of the story that makes such a deep impression on Spade. Its significance is also not lost on Marcus, who contends that the parable illustrates a particular aspect of the human condition: how "we will continue to persist [in behaving sanely, rationally, sensibly, and responsibly] even when we know that there is no logical or metaphysical, no discoverable or demonstrable reason for doing so." ${ }^{.96}$ For Marcus, it is Spade's (and, by authorial extension, Hammett's) awareness of these "forces and beliefs and contingencies that guide [Spade's] conduct and supply a structure to his

\footnotetext{
${ }^{94}$ Dashiell Hammett, "The Maltese Falcon," in The Maltese Falcon and The Thin Man (New York: Vintage Books, 1964), 57.

${ }_{95}$ Ibid.

${ }^{96}$ Marcus, 201.
} 
apparently enigmatic behaviour." ${ }^{, 97}$ Marcus further contends that this outlook, which admits "complexity, ambiguity, and [a] sense of the problematical" are not confined to this one story but "permeate Hammett's work and act as formative elements in its structure, including its deep structure. ${ }^{, 98}$ A closer examination of The Maltese Falcon, particularly with respect to the characterization of its detective-hero Sam Spade, finds justification for Marcus' claim.

In his introductory portrayal of Spade, Hammett describes him as a "blond Satan," which, although explicitly directed at his physical features, implicitly applies to his moral nature as well. ${ }^{99}$ It is clear from the outset that the detective-hero of this new type of detective story is inscribed as fundamentally ambiguous, having attributes that are, at the same time, angelic and sinister. As a narrative strategy, this characterization is designed to keep the reader unclear on Spade's motives as the story progresses, and it prefigures his sometimes erratic behaviour throughout. For example, although his purpose is at core to enact justice, there are several moments in the story where it seems as if Spade is bent on capitalizing on the criminal activity he is investigating, making deals at various point to secure for himself either fees for recovering the Falcon or the treasure itself. At the story's conclusion, is it unclear what Spade's actions would have been had the Falcon been real and not a forgery, whether he would have succumbed to its gilded allure and forgotten the murder of Miles Archer, or whether he would have pursued justice for his partner despite the opportunity to enrich himself.

\footnotetext{
${ }^{97}$ Ibid., 200.

${ }^{98}$ Ibid., 201.

${ }^{99}$ Hammett, 3.
} 
When, late in the story, he is asked by O'Shaughnessy if their love - mutually expressed by this point- - tips the balance in favour of his saving her from the gallows, Spade replies unironically "Well a lot of money would have been at least one more item on [your] side of the scale." 100 In fact, the nobility he exhibits by giving her up to the police - moral justice, loyalty to his partner, professional honour-is undercut by the overt self interest implied in a celebrated speech he delivers: "One of us has got to take [the fall]...They'd hang me for sure. You're likely to get a better break...I won't play the sap for you." ${ }^{101}$ At the very least, it is certainly arguable that, in the end, Spade does not so much seek justice as scramble to extricate himself from his predicament. In pursuit of this objective, O'Shaughnessy is expendable. In the film version, Bogart's performance faithfully renders the moral ambiguity of this character, effectively enacting the "wolfish grin" that Hammett repeatedly ascribes to Spade in the novel. He is, however, certainly not presented as "mean" in Chandler's sense. Rather, it is fair to say that Bogart as Spade emits a rather sardonic, though playful, persona and even, on occasion, appears genuinely noble. It is clear that both the novel and film version of The Maltese Falcon channel the philosophy of the Flitcraft story. It is possible to perceive the lesson of that parable - that life is fundamentally inscrutable - inscribed into the enigmatic actions of Spade, who can subsequently be read as simply adjusting himself according to unfolding events; adjusting himself, that is, to beams either falling or not falling.

\footnotetext{
${ }^{100}$ Ibid., 195.

${ }^{101}$ Ibid., 193.
} 
The film versions of The Maltese Falcon and The Big Sleep are both considered examples of film noir, ${ }^{102}$ a term coined in 1946 by French film critics to describe a darkly pessimistic trend they noticed in the American films flooding post-war French cinemas. ${ }^{103}$ Although a standard definition is elusive, "film noir" loosely encapsulates those American films of the 1940s and 1950s that depict a world of "dark, slick city streets, crime and corruption" and are informed by some combination of despair, cynicism, and fatalism. ${ }^{104}$ Scholars frequently point to a wide array of influences that brought about the film noir, but they all concede the significant role played by hardboiled fiction. ${ }^{105}$ In a celebrated essay, Paul Schrader asserts that hardboiled fiction gave film noir "preset conventions of heroes, minor characters, plots, dialogue, and themes." These story elements were in turn married to a visual style imported from Germany - a dark, expressionistic style at odds with the luminous glamour typically associated with Hollywood. In film noirs, chiaroscuro lighting designs were frequently employed. Shadows were sometimes so oppressive they would swallow characters whole. Schrader states that the majority of scenes in a typical film noir "are lit for night," and that "Ceiling lights are hung low and floor lamps are seldom more than five feet high." Graphically, "oblique and vertical lines are preferred to horizontal." Light and shadow in

\footnotetext{
${ }^{102}$ Although I identify the term "film noir" as a style, it can also be identified as a genre, a mood or tone, or a cycle of films. For a summary of the term's various functions see Andrew Dickos, Street With No Name: A History of the Classic American Film Noir (Lexington: The University Press of Kentucky, 2002), 1-9.

${ }^{103}$ The specific French film critic credited with coining the term is Nino Frank. See Raymond Borde and Etienne Chaumetron, A Panorama of American Film Noir: 1941-1953, trans. Paul Hammond (San Francisco: City Lights Books 1955), 1.

${ }^{104}$ Paul Schrader, "Notes on Film Noir," in The Film Genre Reader II, ed. Barry Keith Grant (Austin: University of Texas Press, 1995), 171.

${ }^{105}$ The best account of film noir's influences remains Paul Schrader's "Notes on Film Noir."

${ }^{106}$ Schrader, 174. Other scholars who remark on the hardboiled influence include Borde and Chaumetron in A Panorama of Film Noir, Dickos in Street With No Name, and Sheri Chinen Biesen in Blackout: World War II and the Origins of Film Noir (Baltimore: The John Hopkins University Press, 2005.
} 
film noir are choreographed to produce a variety of disquieting shapes: "jagged trapezoids, obtuse triangles, vertical slits." The resulting screen space, concludes Schrader, is restless, unstable, and full of tension. ${ }^{107}$ The dark, unsettling visual style of film noir suited perfectly the tentative scopic assumptions of hardboiled fiction. The ambiguity, complexity and uncertainty that Hammett and Chandler incorporated into the detective genre was visually transposed onto the screen in the form of film noir.

The 1941 film version of The Maltese Falcon is considered by many to be the very first film noir. ${ }^{108}$ It exhibits all the qualities that would eventually define this style of film and set the precedent for those that followed. To be sure, The Maltese Falcon is not as daring in its use of darkness, shadow and oblique graphics as are later film noirs but, even in rudimentary form, the style is unmistakably present. It is evident in the expressionistic "Spade and Archer" shadow cast onto the floor of the detectives' office in the opening scene. We see it as well in the stark staging of the murder of Miles Archer, who meets his demise in the dead of night, standing against an unperturbed blackness. Only Archer's face is illuminated as he is shot, a necessary conceit that registers an important narrative detail: his astonishment at the identity of his killer. Graphically, oblique lines also figure prominently in the film. The most striking example occurs when Spade surveys the crime scene from the top of the bluff where Archer's body is found. An angled fence post, the irregular pattern of the bluff and the expressionistic cityscape in the far background are all in graphic conflict with one another. The visual tension in

\footnotetext{
${ }^{107}$ Schrader, 175 .

${ }^{108}$ Both Schrader and Borde and Chaumetron make this claim in their studies. The film also figures prominently in the film noir accounts of Dickos and Biesen.
} 
this shot is palpable. In what would become a film noir staple, venetian blinds in The Maltese Falcon are frequently used as an alibi: the angled shadows they cast against the background are arranged to disrupt the visual pattern of the image. In the film version of The Maltese Falcon, these film noir techniques reproduce visually the scopic uncertainty of the source material.

Whereas The Maltese Falcon is film noir as it appears in its formative stage, The Big Sleep is a more sophisticated film noir. Raymond Borde and Etienne Chaumetron, who together wrote the first comprehensive account of film noir, declare that The Big Sleep is "a veritable classic of the [film noir] genre, the essential laws of which it encapsulates." ${ }^{109}$ The Big Sleep takes up the visual design introduced in The Maltese Falcon and other early film noirs and further elaborates its pattern. Its film noir pedigree is assured during the opening credits, which unspool over a stark, silhouetted image of the film's leads, smoke from their cigarettes adding to the dark mood. More than The Maltese Falcon, The Big Sleep is highly selective about what it lights, exhibiting an overall darker tone with higher contrasts and deeper shadows. Such an approach allows for more intricate graphic arrangements, as attested by the scene in which Marlowe breaks into Geiger's house and finds both a dead body and a drugged Carmen. The central room in this house, to which the film returns again and again, is full of shadows, with an inscrutable graphic pattern apparently dictated by oriental motifs.

The Big Sleep begins in daylight but quickly travels along a visual trajectory that takes it into the darkness of night, whence it spends most of its time. Rain figures

\footnotetext{
${ }^{109}$ Borde and Chaumetron, 56.
} 
prominently in these nighttime scenes, although the rain is surpassed in its obscuring effect by the eventual introduction of an impenetrable fog. The fog persists throughout the last act of the film, from Marlowe's beating in the alley by his office building to the final scene at Geiger's house. The fog also plays a decisive role in the narrative's climax. After a dramatic confrontation, Marlowe forces villain Eddie Mars outside where, due to the dense fog, Mars' own henchmen mistake him for Marlowe and cut him down in a barrage of bullets. The fog is an apt metaphor for the inherent ambiguity of the film noir style, an ambiguity dramatized in The Big Sleep's final few moments. The last shot of the film has Marlowe and Vivian Sternwood, by now romantically linked, in a medium close-up, awaiting the police. The film fades to black before a complete resolution transpires; the romantic couple do not embrace or otherwise indicate their affections. Instead, they stand fearful and nervous since they are not secure from the henchman outside. The conventional closure one expects - a clear indication of security restored-is demonstrably lacking in The Big Sleep. Instead, the film ends by the brink of fog, on this tense, ambiguous moment that is both, at the same time, triumphant and unresolved. The tense ambiguity that ends The Big Sleep, and was inherited from the hardboiled narrative form, effectively encapsulates the general tenor of film noir.

With Cartesian Perspectivalism increasingly contested as the dominant scopic regime in a variety of spheres, including visual art and philosophy, detective fiction responded by undergoing a fundamental mutation, one that took into account the growing sense of scopic uncertainty. The classical model was adapted by a new generation of detective fiction writers--Hammett and Chandler chief among them—and developed into 
the hardboiled genre, a new breed that incorporated ambiguity, acute complexity, and doubt into its formula. Whereas the classical detective assumed a Cartesian perspective of partition and distance whose equivalent metaphor was a window on the world, the hardboiled detective assumed one of integration and immanence, stepping through the window and implicating himself in the world he investigates. Hardboiled fiction also trod new ground by constructing detective-heroes with more plausible capacities for cognitive reasoning, tacitly (or openly in Chandler's case) acknowledging the impossibility of conforming to the Cartesian ideal represented by the Great Detective. When hardboiled fiction was transposed to the screen, it did so under the guise of film noir, a dark visual style that perfectly suited the hardboiled narrative. The next chapter will follow the trajectory of scopic regimes to its next significant shift, one coterminous with postmodernism and marked by an outright rejection of Cartesian Perspectivalism. It will illustrate how this shift from one scopic regime to another was captured in a single cultural text, a detective film and the central object of this study: Chinatown. 


\section{The Obscurity of Chinatown}

"...postmodernism may be understood as the culminating chapter in a story of the (enucleated) eye."110

From the validation of Cartesian Perspectivalism in the work of Edgar Allen Poe, to the hint of visual uncertainty woven into the stories of Dashiell Hammett and Raymond Chandler, the framework devised for this study suggests a correlation between dominant modes of observation and attendant developments in detective fiction. In the previous chapter, we identified a shift in visuality early in the $20^{\text {th }}$ century that disrupted the hegemony of Cartesian Perspectivalism, imbuing the scopic field with an overall sense of uncertainty. The Great Detective, who gave supreme credence to the power of sight, gave way to the more tentative perspective of the hardboiled sleuth. This emerging pattern indicates that the detective genre accommodates transformations in the visual order through congruous alterations in its conventions and thematic concerns.

The arrival of postmodernism in the latter half of the century heralded another transformation in the visual order. However, whereas the first shift entails the censure of one particular mode of observation while preserving an overall bias towards vision, postmodernism entailed a more thorough rejection of ocularcentrism in any guise. In this new scopic mode, uncertainty has given way to incredulity, leading to what Martin Jay describes as "a denigration of vision." Determining the effects of this denigration on concurrent detective fiction will form the core of this chapter, culminating in a detailed

${ }^{110}$ Jay, 545. 
look at Chinatown and its intricately elaborated scopic architecture. The first task in this undertaking, however, will be to describe in more detail the collapse in esteem of what was once considered the noblest of the senses.

Jay claims that the philosopher who provides the most "quintessential articulation" of the anti-ocular discourse traced so exhaustively in his study Downcast Eyes is Jean-Paul Sartre. ${ }^{11}$ Sartre's denunciation of the hypertrophy of the visual takes the form of several familiar accusations; among them, that it abets the domination of nature and privileges space at the expense of time. Of particular interest to this study is his charge that the ocularcentic bias practiced by the West has led to a problematic epistemology. According to Jay, over the course of his career Sartre became increasingly haunted by the question of achieving a totalistic knowledge of reality, the inevitable failure of which the philosopher partly attributed to a misguided faith in the power of vision. The problem, Sartre claims, lay in the incapacity of our limited cognitive faculties to secure a complete picture of the external world. As Jay, interpreting the philosopher, states, "The primary impediment to knowing the whole... was the situated nature of our individual vantage point, which could not see beyond a limited horizon of knowledge." 112 No Cartesian metasubject existed, according to Sartre, who could totalize the whole and see its totalization via an ideal perspective. No vantage point could be assumed that encompassed the entire labyrinth at once, forever dooming us to wander its impenetrable

\footnotetext{
${ }^{111}$ Ibid., 275.

${ }^{112}$ Ibid., 291.
} 
network from within. ${ }^{113}$ As we shall see, this principle was to play a central role in the burgeoning order of postmodernism.

Sartre was not alone among French intellectuals in critiquing or outright rejecting aspects of the hegemonic visual order inherited from Descartes. In his study, Jay methodically probes the work of a wide array of French thinkers and details their objections against the historical privileging of vision. The list runs rather long and includes such luminaries as Jacques Lacan, George Bataille, Louis Althusser, Jacques Derrida, Guy Debord, Roland Barthes, Luce Irigaray, Christian Metz, and Michel Foucault. Each, according to their own area of interest, contributed to a sustained attack on the hypertrophy of the visual. In fact, so vigorous and prevalent were these discursive attacks in the 1960 s and 1970 s that, taken together, they constituted what Jay describes as an anti-ocular "frenzy" or "panic."114 Moreover, although Sartre remains the most articulate critic of the received visual order, Foucault undoubtedly stands as its harshest. We will thus turn to Foucault's thoughts on visuality in order to indicate the degree of denigration to which vision was eventually subjected.

With Foucault, it was not so much a question of refuting the Cartesian visual order - the most common line of attack - as it was of reversing its value. As we have seen, the Enlightenment was a movement whose emancipatory impulse was predicated on the presumed power to master the world through visual means via the linkage of lucidity and rationality. Far from rejecting the feasibility of this project, Foucault challenged its

\footnotetext{
${ }^{113}$ For an account of Sartre's struggle with this issue, see Martin Jay, Marxism and Totality: The Adventures of a Concept from Lukás to Habermas (Berkeley: University of California Press, 1984), chap. 11.

114 Jay, Downcast Eyes, 484.
} 
supposed benevolence by demonstrating how in some ways its illuminating power was channeled towards socially oppressive ends. "The 'Enlightenment' which discovered the liberties," he argued, "also invented the disciplines." ${ }^{115}$ He illustrated this power in action via the allegorical example of the Panopticon, a model prison designed (but never built) by Jeremy Bentham in 1791. This prison operated on the principle that discipline could become self-regulating given the appropriate visual economy, one where the prisoners were under constant and complete surveillance from an unseen power or authority. The anonymity of the disciplining figure coupled with the constant sensation of being watched would, in effect, internalize the external gaze, resulting in a scenario in which prisoners would police themselves. Foucault felt that Enlightenment forces make use of visuality in precisely the same fashion, enforcing normative social behaviour through what Jay describes as the "vigilance of intersecting gazes" instead of an explicit agent of authority. ${ }^{116}$ For Foucault the conclusion was inevitable: our society is one extended "panoptic machine" 117 in which a self-inflicted conformity has replaced the visible displays of sovereign power once needed to instill docility in the populace. Foucault's was thus, according to Jay, "a social and political critique in which voir was linked with both savoir and pouvoir," ${ }^{118}$ where sight and knowledge worked hand in hand to enable a form of social control.

Worth noting is also the one exception to this increasingly virulent anti-ocular discourse: the contribution to the debate of philosopher Maurice Merleau-Ponty. I turn to

\footnotetext{
${ }^{115}$ Michel Foucault, Discipline and Punish: The Birth of the Prison, trans. Alan Sheridan (New York: Vintage Books, 1979), 222.

116 Jay, 411.

${ }^{117}$ Foucault, 217.

118 Jay, 383.
} 
his work briefly here because of its expressed affinity with the hardboiled genre's strategy of coping with an increasing distrust of the Cartesian visual order. Although Merleau-Ponty also rejected the Cartesian ideal as the dominant scopic regime, he sought, in ways that recall the reaction of the detective genre, to defend an alternative philosophy of the visual, one that conceived of vision as homologous with the world within which it operated and not somehow external to it. In a "post-Euclidean" climate, Merleau-Ponty insisted, we are now aware that the objective world is not a geometrically spatialized scene viewable from outside and above as it seemed to Descartes. In contrast to Descartes' notion of vision as a perspective on the world, Merleau-Ponty felt vision should be conceived as a perspective from in the world. "I do not see it according to its exterior envelope," he claimed, "I live it from the inside; I am immersed in it." ${ }^{119}$ There is clearly a discernible correspondence between Merleau-Ponty's conception of visuality and the scopic mode adopted by detective fiction to accommodate a growing unease with a Cartesian perspective. Each reacted not by rejecting the visual outright, as was becoming increasingly common, but through a more qualified reconsideration of its illuminating value. However, Merleau-Ponty's attempts to advance such a conception of the visual, and thus rescue vision from complete denigration, were unsuccessful and did nothing to stem the anti-ocular tide sweeping through French philosophical circles. In retrospect, one can judge the alternative mode of visuality advocated by Merleau-Ponty and expressed in hardboiled detective fiction as simply a way station on a relentless trajectory towards a complete vilification of this once noble sense.

\footnotetext{
${ }^{119}$ Maurice Merleau-Ponty, "The Eye and the Mind" in The Primacy of Perception, trans. James M. Edie (Evanston: Northwestern University Press, 1964), 178.
} 
The widespread condemnation of visuality articulated by philosophers like Sartre and Foucault critically undermined the Enlightenment principle of linking lucidity and rationality. According to these thinkers, it was no longer a question of doubt in a particular scopic regime; it was, rather, a firm conviction that faith in the illuminating power of the Enlightenment project to bring about its entwined objectives of enlightened reason and comprehensive liberty was false, misguided, even dangerous. Moreover, this philosophical movement did not appear in a vacuum or develop as some isolated intellectual event; it was part of a much broader phenomenon that, for many, constituted a clear departure from the social, cultural, and economic framework that preceded itthough what degree of departure is still a matter of contention. I am speaking here of postmodernism, which emerged following the end of the Second World War at a time that roughly coincides with the launch of the French wave of anti-ocular philosophy I have been describing.

Their synchronized appearance is, of course, not by chance since the critical undermining of Enlightenment principles represented by this discursive thread can be designated as one of the many facets of postmodernism itself. Indeed, led by JeanFrançois Lyotard, French thinkers in general have been at the forefront of attempts to theorize the implications of a shift from a modern to a postmodern sensibility. Lyotard's American counterpart in this undertaking is Fredric Jameson, whose Postmodernism, Or, The Cultural Logic of Late Capitalism stands as perhaps the most comprehensive account of this phenomenon. Because of their standing in the field, I will be relying on their insights concerning the postmodern in the ensuing analysis of detective fiction, with 
particular emphasis on the scopic dimensions in their work. However, before we examine the specifics of their respective theoretical positions, it is necessary to provide some background to this somewhat elusive concept.

Postmodernism is a notoriously difficult concept to articulate with any degree of assuredness since by its very nature it is suspicious of the definitiveness of any claims, the rigidity of any boundaries, or the existence of absolutes of any kind. Any attempt to fix postmodernism within stable conceptual limits violates its very premise, an impasse which has historically plagued the project of its theorization. No less an authority than Jameson himself argues that the concept "is not merely contested, it is also internally conflicted and contradictory. ${ }^{, 120}$ Nevertheless, it has proven useful as a critical tool in describing the effects, in all spheres, of a waning modernist sensibility. Postmodernism's critical potential has been harnessed by re-classifying its "indefiniteness" as the organizing principle according to which judgments can be made. In this way the "conflicted and contradictory" premise underlying the postmodern resolves the dilemma of which it was also the source. However paradoxical such a maneuver might seem in theory, it has, as we shall see, proven extremely useful in practice, providing Lyotard, Jameson and other postmodern thinkers a way to overcome the theoretical impasse of the concept and liberate postmodernism's critical potential.

In the realm of aesthetics, for example, Lyotard describes the effects of postmodernism precisely as a kind of response to a perceived absence of dominant aesthetic models. He states that postmodern writers and artists "are not in principle

\footnotetext{
${ }^{120}$ Fredric Jameson, Postmodernism, or, The Cultural Logic of Late Capitalism (Durham: Duke University Press, 1991), xxii.
} 
governed by pre-established rules, and they cannot be judged according to a determining judgment, by applying familiar categories to the text or to the work. Those rules and categories are what the work of art itself is looking for." ${ }^{121}$ The lack of a fixed organizing principle meant to guide aesthetic standards vanishes in the postmodern era, leaving the postmodern text or work of art to search for those very categories against which it can be judged. Lyotard acknowledges, as well, that this new type of aesthetic practice has its source in the emerging uncertainty that took root in the late $19^{\text {th }}$ century, and that, as noted in the previous chapter, was visually registered in a variety of modernist aesthetic movements. However, in Lyotard's conceptualization, doubt is no longer simply a subject of aesthetic interest, as it was in modernism; with the advent of postmodernism, it has become the very bedrock of aesthetic practice.

Lyotard's thoughts on postmodern aesthetics are part of a larger project whose objective is to critically interrogate some of the basic principles of the Enlightenmentthe same principles that determined the scopic assumptions of classical detective fiction. In The Postmodern Condition, a philosophical work whose subtitle-A Report on Knowledge-discloses its central concern, he attempts to both describe and respond to the implications of a shift away from the epistemology of the Enlightenment and towards that of the postmodern. According to Lyotard, one of the casualties of the groundlessness imposed by postmodernism is the Enlightenment principle of totality_in particular, the variant that proposes a telos to enlightened reason in absolute knowledge. In a postmodern schema, this notion is acknowledged as utterly unfeasible. In the foreword to

\footnotetext{
${ }^{121}$ Jean-François Lyotard, The Postmodern Condition: A Report on Knowledge, trans. Geoff Bennington and Brian Massumi (Minneapolis: University of Minnesota Press, 1997), 81.
} 
Lyotard's book, Jameson picks up on this theme and states bluntly that the rhetoric of totality or totalization has become, in the postmodern era, "the object of a kind of instinctive or automatic denunciation" by the intellectual community at large. ${ }^{122}$ According to Jay, this anti-totality impulse also has a visual dimension. He states that "if postmodernism teaches anything it is to be suspicious of single perspectives, which...provide totalizing accounts of a world too complex to be reduced to a unified point of view." ${ }^{p 123}$

For Lyotard, the dismissal of the totality model takes the form of a critical stance against meta or grand narratives, those totalizing cultural narratives taken to explain all historical knowledge and experience. In their place he argues for the embracing of petits récits or "little" narratives, part of a prescriptive framework he devises that also privileges the plurality of the local over the singularity of the universal, and the diversity of paralogy over the uniformity of homology. In a general sense, this position stipulates that a postmodern sensibility rejects a bounded totality and accepts, in its place, a limitless infinity. Given the anti-Enlightenment current in this philosophy, it should come as no surprise that this position is, in another work, explicitly laid out in visual terms: "The idea that thinking is able to build a system of total knowledge about clouds of thought by passing from one site to another and accumulating the views it produces at each site—such an idea constitutes par excellence the sin, the arrogance of the mind." 124 Here, Jean le Rond d'Alembert's notion of adopting an expansive view of the labyrinth in

\footnotetext{
122 Ibid., xix.

123 Jay, 545.

124 Jean-François Lyotard, Peregrinations: Law, Form, Event (New York: Columbia University Press, 1988), 6-7.
} 
order to perceive the totality of its contents is implicitly challenged as an enterprise so woefully misguided as to be morally suspect.

For detective fiction, a rejection of totality along the lines Lyotard suggests has fateful implications. Considered in light of Lyotard's theories, the central role of a detective is as architect and guardian of a master narrative. This is more true for the classical detective, but applies in strong measure to the hardboiled model as well. In detective fiction, the apparent disorder of evidence is collected, organized and reconfigured into a coherent picture in which each piece of the puzzle is meaningfully integrated into the whole. This totalizing picture reveals its function as master narrative at the story's conclusion when, for the benefit of both characters and reader, the detective relates the events of the mystery in story form. To invalidate the authority of the master narrative and, by implication, its corresponding cognitive image of totality, as Lyotard's model of the postmodern suggests, is to invalidate the authority of the detective.

A second implication for detective fiction's scopic assumptions in the postmodern era that is suggested by Lyotards's account is organized around the interrogation of empirical science, one of the genre's epistemological allies. According to Lyotard, the postmodern dismissal of metanarratives not only refutes the Enlightenment principle of totality, it also entails a "crisis of legitimation" for the knowledge acquired through science: "The crisis of scientific knowledge, signs of which have been accumulating since the end of the nineteenth century, ...represents...an internal erosion of the legitimacy principle of knowledge. ${ }^{, 125} \mathrm{He}$ also clearly states what he believes to be the

\footnotetext{
${ }^{125}$ Lyotard, The Postmodern Condition, 39.
} 
cause of this crisis: "the decline of the unifying and legitimating power of the grand narratives of speculation and emancipation. ${ }^{.126}$ In brief, Lyotard argues there has been a growing awareness that speculative knowledge of the scientific kind can only be legitimated by referring to its own statements in a discourse that already presupposes its legitimacy. In other words, scientific knowledge has no original "legitimating" source, other than the now discredited grand narratives of "speculation and emancipation." Lyotard argues that, as a consequence, the type of denotative discourse that had previously constituted the general field of science "does not really know what it thinks it knows. ${ }^{\text {"127 }}$ Paradoxically, what is produced by science is, according to this view, the "unknown" 128 in a process that, although it neutralizes the issue of universal legitimation, forever puts the horizon of certainty out of reach. Such a conception of science, when applied to the detective genre, effectively renders the actions of the detective futile. If, for Lyotard, postmodernism is an opportunity to escape the stultifying effects engendered by Enlightenment principles, for Jameson it represents a disturbing aporia that must be actively countered. As a result of the Marxist perspective he adopts, Jameson's theoretical model of the postmodern is one in which its social, cultural, aesthetic, and political implications are largely determined by its corresponding economic structure, variously expressed as late, third stage, or multinational capitalism. He argues that this most recent mutation in the economic system promotes a certain debilitation that is both socially felt and aesthetically registered in postmodern art, though its true crime

\footnotetext{
${ }^{126}$ Ibid.

${ }^{127}$ Ibid., 38.

${ }^{128}$ Ibid., 60.
} 
for Jameson is in how it paralyzes political action by neutralizing ideological critique. He theorizes that this debilitating effect is caused, in part, by a disruption of our cognitive processes.

The difficulty in bringing the conceptual outlines of postmodernism into focus, suggests Jameson, is part of a larger dilemma brought about by the postmodern, namely the incapacity of our cognitive faculties to adequately contend with the new global order it has prompted. He argues that postmodernism engineers a new kind of inscrutable space, what he calls "postmodern hyperspace." Using the unintelligible design of The Westin Bonaventure hotel in Los Angeles as exemplary, he argues that postmodern hyperspace transcends "the capacities of the individual human body to locate itself, to organize its immediate surroundings perceptually and cognitively to map its position in a mappable external world." 129 This precipitous loss of bearings, however, proves to affect more than just the physical body in the built environment. The cognitive predicament posed by postmodern hyperspace, Jameson continues, "stands as the symbol and analogon to that sharper dilemma which is the incapacity of our minds, at least at present, to map the great global multinational and decentered communicational network in which we find ourselves caught as individual subjects." ${ }^{\text {130 }}$ Thus Jameson puts the blame of our inability to map our coordinates squarely at the feet of multinational capitalism, whose emergence following the Second World War exponentially increased the complexity of the network of systems - previously contained within municipal or national boundarieswith which we must daily contend. This network, now elaborated on a global scale, has

\footnotetext{
${ }^{129}$ Jameson, 44.

${ }^{130}$ Ibid.
} 
pushed our cognitive capacity beyond its natural limit, leaving us powerless to counteract its adverse influence: "we know that we are caught within these more complex global networks, because we palpably suffer the prolongations of corporate space everywhere in our daily lives. Yet we have no way of thinking about them, of modeling them, however abstractly, in our mind's eye."131

Jameson argues that a solution to this cognitive dilemma would necessarily involve a practical reconquest of a sense of coordinates wherein an awareness of local positioning relative to the overall design of postmodern space is somehow made available. For this purpose, he advocates for the development of what he calls "an aesthetics of cognitive mapping,"132 a new, hypothetical cultural form whose methods would be akin to cartography. Given the particular difficulties posed by postmodern space, the traditional mode of positioning oneself - via an exacting knowledge of the network being traversed-is not an option. Since knowledge of the totality of the system is unattainable, an aesthetics of cognitive mapping would, instead, have the function of articulating the coordination between a local position and the system at large. In Jameson's words, cognitive mapping would "enable a situational representation on the part of the individual subject to that vaster and properly unrepresentable totality which is the ensemble of society's structures as a whole."133 Since Jameson's "situational representation" is based on relative—as opposed to absolute-values, it overcomes the paralyzing effects engineered by postmodernism while simultaneously respecting its

\footnotetext{
${ }^{131}$ Ibid., 127.

${ }^{132}$ Ibid., 51.

${ }^{133}$ Ibid.
} 
internal logic; the "totality" remains directly unknowable, but through some as yet undiscovered mediating force, our relationship to that totality can be made apparent. By this method, implies Jameson, our bearings can be restored. The intransigence of the problem is quickly revealed, however, as he offers no concrete measures to realize an aesthetics of cognitive mapping, nor have any been proposed since his introduction of the concept.

Jameson's hope for a solution to the cognitive problems caused by postmodernism was anticipated in certain critical remarks on detective fiction he made earlier in his career. In an article on the work of Raymond Chandler, Jameson wrote the following: "the detective...fulfills the demands of the function of knowledge rather than that of lived experience: through him we are able to see, to know, the society as a whole, but he does not really stand for any genuine close-up experience of it." ${ }^{, 134}$ With a retrospective eye, we can read in this passage a conception of the hardboiled detective as fulfilling the role of cultural mapper, using his superlative vision to mediate our relationship to the complex network of systems that surrounds us and the lived experience that that system obscures. However, as we shall see, the postmodern detective refutes this possibility.

Between the overt repudiation of the hypertrophy of the visual in post-war French intellectual discourse and the more general refutation of Enlightenment principles elaborated in postmodern theory, faith in the scopic regime of Cartesian Perspectivalism quickly dissipated. This visual order-already contaminated by uncertainty as early as the

\footnotetext{
${ }^{134}$ Jameson, Poetics of Murder, 127-128.
} 
late $19^{\text {th }}$ century—accelerated along a declining trajectory as it passed into the postmodern era, eventually losing all credibility, and even, in some quarters, succumbing to full-fledged denigration. This was a considerable reversal after centuries of thought that had steadfastedly held to the doxa of enlightened reason's limitless potential. As a result, incredulity was now the generally adopted stance when considering the epistemological implications of visuality.

We have already established the crucial role that Cartesian Perspectivalism played in the genesis of detective fiction and the way in which Enlightenment principles were structured into the very fabric of the genre. We have also established the way in which detective fiction adjusted its generic structure — generating the hardboiled variety-in order to accommodate a growing scopic uncertainty. The next step is, therefore, to determine how detective fiction reacted to the new visual order brought about by postmodernism - to determine, that is, if the pattern that has been established between detective fiction and its attendant scopic regime holds in the postmodern era, and, if so, in what configuration.

In the previous chapter, our task of identifying the adaptive response from detective fiction in the face of an altered scopic mode was facilitated by "The Simple Art of Murder," Raymond Chandler's treatise on the hardboiled genre. In describing the successor to the classical detective story chiefly through its distinguishing innovations, a newly-minted dominant model was clearly articulated and sharply defined against its predecessor. No such useful treatise exists for the postmodern detective story since the 
innovations visited on the genre in the postmodern era lack a cohesive principle that would define a dominant model as such; in keeping with the pluralism of the postmodern, detective fiction adapted itself to the new visual order in a variety of distinct ways. Consequently, instead of considering a dominant model, it is more appropriate to discuss the postmodern detective story in terms of trends within a given context. Our context, as defined by scopic regimes, yields a very discernible trend, one in which certain high profile detective stories confront the postmodern visual order directly and exhibit a decidedly anti-ocular prejudice.

One film scholar in particular has already perceived this trend. In "Flaws in the Iris: The Private Eye in the Seventies," David Lyons describes how the innovations of The Long Goodbye and Chinatown originate in their self-reflexive awareness of the codes and conventions of the hardboiled genre. Unfortunately, despite its title, Lyons' article is full of digressions and only briefly touches upon the issue of visuality. While he recognizes that both films share similar scopic assumptions, he fails to elaborate this point in any detail. Also, his reading of the visual dimensions of detective fiction does not admit nuance; he confuses the scopic uncertainty of traditional hardboiled fiction with the scopic incredulity of its postmodern counterpart. He implies that whereas the issue of visuality is latent in traditional hardboiled fiction, the condition of self-awareness in the 1970s films brings this issue to the surface. Lyons does not consider the differences further. Moreover, his specific analysis of Chinatown, complete with references to the American socio-political backdrop of the 1970s, simply recapitulates the standard 
account of the film. Nevertheless, he does make a few suggestive observations concerning visuality that warrant pursuit.

With The Long Goodbye, director Robert Altman's explicit purpose was to satirize the hardboiled fiction of Raymond Chandler by adapting one of Chandler's own novels in line with a 1970 s sensibility. ${ }^{135}$ The anachronistic result prompts wholesale ridicule of the once-dignified genre, with the most potent derision reserved for the Philip Marlowe character itself. As one commentator notes, "the detective, once an ideal of American manhood, is [in the hands of Altman] nothing but a clown." ${ }^{136}$ Although his ultimate purpose was to expose the knightly Philip Marlowe as a fraud, Altman was also sensitive enough to the scopic assumptions in the source material to address them in his critique. As Lyons notes, in the film version of The Long Goodbye "important things are seen—often misseen—through glass."137 These "layers of glassy transparencies," he continues, "point to epistemological paralysis." ${ }^{138}$ His central supporting piece of evidence is the key moment of the suicide of Marlowe's charge in the film, Roger Wade, an event which is glimpsed by the befuddled detective through a window. Lyons contends that "the intervening window is at once, for Marlowe, means of perception of the event and symbol of his inability to really comprehend what is happening."139 According to this reading, the film exploits the investigative function of the detective to illustrate a cognitive gap between seeing (perception) and knowing (comprehension).

\footnotetext{
${ }^{135}$ Paul Gardner, “'Long Goodbye' Proves a Big Sleeper Here,” New York Times, November 8, 1973, 59.

${ }^{136}$ Oliver, 242.

${ }^{137}$ Lyons, 49.

${ }^{138}$ Ibid.

${ }^{139}$ Ibid.
} 
Moreover, this cognitive failure is occasioned by an "intervening window," suggestively recalling a Cartesian perspective.

The detective-as-befuddled-clown, another postmodern trend in the genre, can also be perceived in the 1970s detective films Night Moves (1975) and The Late Show (1977), although neither addresses the underlying scopic assumptions of detective fiction as conscientiously as does Altman's film. However, The Long Goodbye is eclipsed in this regard by Blade Runner (1982), a hardboiled inspired, postmodern detective film that more studiously—and more seriously—interrogates the scopic underpinnings of the genre. In fact, its rather obsessive ocular preoccupations-which are organized around the existential implications of a visually-biased epistemology—are perhaps too densely packed to attempt their elaboration here. It suffices to note that, of the films that fall within the anti-ocular trend I have described, Blade Runner provides perhaps the most systemic critique of the presumed relationships between vision, emancipation, and ontology as they are traditionally resolved in the act of investigation.

As considered within the context of scopic regimes, the detective film Chinatown stands out as a unique case. Whereas postmodern, anti-ocular films like The Long Goodbye and Blade Runner mark a definitive break with the more tentative scopic uncertainty of traditional hardboiled fiction, Chinatown is more ambiguous. If more attentive to its ocular preoccupations than Lyons, one perceives how Chinatown exhibits both the uncertainty of traditional hardboiled fiction and the incredulity of its postmodern counterpart; each perspective is clearly discernible in the film. Moreover, Chinatown is 
structured in such a way that one perspective rather coherently gives way to the other in a way that can be said to articulate the transition from one visual model to its successor. The film's dual profile does not appear to be the result of a conscious effort on the part of the filmmakers. There is no evidence to suggest that the creative minds responsible actively conspired to design this more elaborative scopic architecture. Rather, the competing perspectives in Chinatown can be read as the result of a disputed split that occurs in the deeper structure of the film, one that can be traced to the clash of sensibilities between its screenwriter and director, Robert Towne and Roman Polanski, respectively.

In Fault Lines, film scholar Mark Horowitz arrives at the conclusion that Chinatown stands as an aberration in the context of Towne's body of work; it is unlike any other film in his oeuvre. Horowitz contends that Chinatown created a "vivid but false impression" of Towne's disposition as a screenwriter, fueling unwarranted expectations that "wreaked havoc with critical perceptions" of his subsequent output. ${ }^{140} \mathrm{He}$ continues that, apart from its "crystalline and succinct" structure, what distinguishes Chinatown from Towne's remaining corpus is its "darkly pessimistic" content. ${ }^{141}$ To a film, Towne's other work exhibit a sensibility that is far more "equivocal," contends the film scholar. ${ }^{142}$ Horowitz argues that responsibility for this career discrepancy ultimately falls to Polanski, Chinatown's director, whose own artistic ambitions reshaped Towne's more optimistic conception of the film into the "darkly pessimistic" one that was eventually

\footnotetext{
${ }^{140}$ Horwitz, 53.

${ }^{141}$ Ibid.

${ }^{142}$ Ibid.
} 
produced. Before we get to the changes imposed by Polanski that altered Towne's original vision, we will take a closer look at the ways in which Towne remained faithful to the hardboiled genre.

The evidence that Horowitz gleans from his exhaustive survey of Towne's work in support of his thesis is compelling. Based on his study, Horowitz concludes that Towne is a "classicist" (as opposed to an "innovator") by nature, one who demonstrates a "craftsmanlike respect for the formal demands of a particular genre." ${ }^{\text {"143 }}$ Towne "does not subvert or 'appropriate' old forms in the postmodern fashion." Rather, "he embraces the conventions of whatever genre he happens to be working in." Horowitz cites Towne's forays into romantic melodrama and restoration comedy as cases in point, but his real target is the screenwriter's handling of the detective story as revealed by early drafts of the Chinatown script. ${ }^{144}$

Horowitz makes the case that Towne invoked the hardboiled genre as he did every other genre: not to critique its assumptions but to work out his particular thematic interests within its established boundaries. Towne's classicist impulses resulted in a Chandleresque, hardboiled detective narrative that left the conventions of the genre relatively intact. The story, for example, takes place during the same era traditionally associated with the genre (the 1930s) and in the same city (Los Angeles), and features character types and plotlines that strongly reference traditional hardboiled fiction. According to Horowitz, however, Towne's respect for the genre exceeded simple appropriation of its recognizable codes. In sharp contrast to Altman's urge to disfigure

\footnotetext{
${ }^{143}$ Ibid., 54.

${ }^{144}$ Ibid.
} 
the genre, Towne deferentially sought to cultivate and amplify its deeper, more elusive dimensions. Horowitz states that Towne "took Raymond Chandler's detective genre and enriched it with a more fully articulated social critique, giving the pessimism inherent in all detective fiction a stronger foundation," but that, at the same time, Towne also "preserved intact Chandler's romantic notion that, despite the odds, there were occasional candles against the darkness." 145

The strongest evidence to support this claim lies in Towne's original conception of one of the film's central plotlines, namely, the attempts made to save an innocent girl, Katherine, from falling under the influence of a malevolent force. Early in the film, detective-hero J.J. "Jake" Gittes is hired by a woman claiming to be Evelyn Mulwray for the purpose of determining if her husband Hollis is having an affair. Jake dutifully spies on Hollis cavorting with a young woman, and assumes they are engaged in adulterous behaviour. However, the Evelyn Mulwray who has hired him turns out to be an imposter. Jake has been duped as part of a larger scheme to locate the young girl in question. He discovers that she is not Hollis' mistress but the authentic Evelyn's daughter and sister Katherine, the product of incest between Evelyn and her father Noah Cross. Because he has "lost" his daughter, the powerful and depraved Noah seeks to replace her with his daughter/granddaughter. However, Noah's attempts to secure possession of Katherine are countered by Evelyn's, and eventually Jake's, efforts to keep her from his destructive and perverse clutches. In Towne's original draft, Evelyn kills Noah and goes to jail, but Katherine, with Jake's help, escapes unharmed. The preservation of Katherine's

\footnotetext{
${ }^{145}$ Ibid., 53. The pessimism he notes only surfaced with the hardboiled genre, for one would be hard pressed to pick out any pervasive pessimism in classical detective fiction.
} 
innocence represents the "candle in the darkness" alluded to by Horowitz. Such an ending, one with some sense of justice enacted amid an otherwise implacably corrupt world, stubbornly conforms to the romantic pessimism invoked by Chandler and the hardboiled school. In this, and in other aspects of his script, Towne remained remarkably faithful to the traditions of the genre.

In particular, the scopic assumptions of hardboiled fiction did not escape Towne's notice, and he imported this aspect of the genre as loyally as he did its romantic pessimism and other central elements. In fact, the visual dimension is inscribed more overtly, although still symbolically, in Chinatown, rather than in the ambiguous and implied manner characteristic of traditional hardboiled fiction. Its thematic centrality is prefigured in the opening shot of the film, a close-up of a photograph that Jake is using to prove a wife's infidelity to a cuckolded client. The visual configuration that is established throughout the film suggests that Jake has superior, though imperfect, cognitive abilities reminiscent of Sam Spade and Philip Marlowe. Although his reasoning and calculations are not always correct, the sense is that Jake's visual bias serves him well, helping him progressively demystify the tangled web of intrigue he encounters. Aided by specular technologies, including binoculars, cameras, and a magnifying glass, Jake collects images throughout the narrative that prove integral to his deductions, even if at first encounter they remain inscrutable.

The example of the counterfeit Evelyn Mulwray, early in the film, is a case in point. Fooled by the imposter, Jake believes he is on yet another assignment by a spouse seeking proof of infidelity. As part of his surveillance, Jake discreetly snaps pictures of 
Hollis and the young girl in order to supply his client with evidence, a method already used to great effect with the cuckold. Yet he misinterprets what he sees between the couple and, as a result, unwittingly plays a role in Hollis' murder. However, he does not allow this inauspicious beginning to defeat him; he quickly regains his composure and proceeds to prove his mettle as a detective. Astute enough to realize his relatively minor role as pawn in a larger conspiracy, Jake sets out to resolve the intricacies of the plot that exploited him and, in so doing, redeem himself. In this ambition he is remarkably successful, an achievement that is largely attributable to a reliance on his exceptional visual acuity. The list of visual clues he collects in this pursuit is rather long; it includes the surveillance photos of Hollis and Noah engaged in an argument; the middle initial "C" on an envelope sent by the authentic Evelyn Mulwray; his relentless spying on Hollis, first with Katherine, then as Hollis investigates both the dry river bed and the water runoff channels; the obituary list in the newspaper to which he was anonymously tipped off; the clues he gathers at the water commissioner's office where Hollis worked, including photographs of the younger Hollis and Noah as partners and Hollis" scribble "7 channels used" on a water table map; the recent activity of land sales in the "Northwest Valley" including the names involved, which he discovers at the hall of records; and, finally, the broken eyeglasses at the bottom of the pond at the Mulwray residence.

Despite the complexity of the case and the apparent randomness of the clues, Jake slowly pieces together the puzzle, bringing into focus the outline of an intricate and malevolent plot that has both public and private implications. Jake's astute observations of the photographs at the Water Commissioner's office and the "C" on Evelyn's 
envelope - which, he discovers, stands for Cross—-lead him to establish the relationship between Noah, Hollis, and Evelyn: Noah and Hollis, once partners in water management, are now enemies; Evelyn is Noah's daughter. Jake's surveillance of Hollis, the cryptic note on the water table map, and his diligent research at the Hall of Records lead Jake to investigate water irrigation practices in the Northwest Valley farmlands. While there, he learns that the farmers are being forced, through nefarious means, to sell their property at cut-rate prices. He perceptively notices that the names on the obituary list match those on the land sales records, a discovery that sheds light on Noah's furtive ambition to surreptitiously buy the land in the valley, bring it a reliable water supply, and then sell the formerly worthless property at tremendous profit. Jake's visual inspection of the names listed at the Mar Vista retirement home confirms his suspicions that Noah has been buying land in the names of the retired or deceased residents in order to camouflage his clandestine plot. In the final analysis, it is Jake who manages to tie together all these threads and surmise that Hollis did not die accidentally but was, in fact, murdered by Noah or his agents.

In spite of this formidable record, commentators frequently contend that Jake, far from possessing judicious visual acumen, has some sort of impaired vision. It is a point typically raised in the service of arguing that the myths elaborated in the hardboiled fiction of Chandler and Hammett are refuted by this film. An exemplary case is MaryKay Gamel, who, in illustrating the parallels between Chinatown and the Oedipus fable, states that Jake's "imperfect knowledge is consistently represented by visual images of flawed sight," and proceeds to list them: photographs that are misinterpreted, or their 
meanings obscure, such as those taken by Jake of Hollis and the girl; the images reversed in rearview mirrors and camera lenses as Jake investigates the case, suggestive of faulty visual perception; the black eye of the cuckold's wife, courtesy of her husband as retribution for "seeing" another man; the "flaw" in the iris of Evelyn Mulwray's eye, which is decimated by a bullet at the end of the film; the broken tail-light on Evelyn's car, echoing the flaw in her iris and foreshadowing her eventual fate. ${ }^{146}$ And then there is the case of what might be considered the master clue: Noah's eyeglasses. On his initial visit to the Mulwray residence, early in the film, Jake spots something at the bottom of the residential pond, and, curious, reaches for it. However, at the crucial moment of their retrieval he is distracted by the sudden appearance of Evelyn, postponing the discovery of the eyeglasses - the key piece of evidence that links Noah to Hollis' murder-until much later. Jake simply fails to fully see them as they lie, semi-obscured, at the bottom of the pond.

Yet, as noted in the previous chapter, these types of errors in cognitive judgment, in which visual information is either misperceived or misread, are characteristic of the scopic assumptions of traditional hardboiled fiction. According to convention, a hardboiled detective is one whose cognitive faculties, though superior, are not of an infallible caliber. This detail was apparently not lost on Towne since its symbolic significance, such as the flaw in Evelyn's iris, pervades the film. Jake must, on occasion, even resort to physical force in the manner of Spade and Marlowe when crucial details elude his deductive grasp. For example, in a scene highly reminiscent of Brigid

\footnotetext{
${ }^{146}$ Mary-Kay Gamel, 155-156.
} 
O'Shaughnessy's forced confession at the hands of Spade in The Maltese Falcon, Jake, intuiting that Evelyn is lying to him, slaps her repeatedly across the face until she finally relents, the truth tumbling out: Katherine is both her sister and her daughter. With that, comprehension dawns on Jake. Like Spade, Jake is astute enough to recognize the truth when he encounters it, however improbable or surprising, because it fits as a piece within the puzzle he is reconstructing. Thus, contrary to received wisdom, the detective's flawed sight in Chinatown does not constitute a break with the conventions of the hardboiled genre. Rather, Towne dutifully constructs a detective-hero who shares with traditional hardboiled sleuths an impressive but imperfect vision.

The eyeglasses are eventually found by Jake, the result of discovering that the pond at the Mulwray residence contains salt, not fresh, water. Hollis was drowned in salt water. In considering these clues, Jake remembers the curious object in the pond that had earlier caught his attention and discovers the eyeglasses, retrieving them for inspection. Although Jake correctly deduces that Hollis must have drowned in the pond, the glasses do not belong to the victim, as Jake first suspects, but to the perpetrator Noah. Evelyn sets Jake straight when she casually mentions that the eyeglasses could not possibly belong to Hollis since he did not wear bifocals. It is Noah who wears bifocals. This revelation allows Jake to integrate properly the meaning of the eyeglasses into his broader investigation in a way that clarifies virtually all of its intricacies. In Towne's version, this sequence is followed by an ending that conforms to a hardboiled ideal: Noah dies, shot by Evelyn; Evelyn is incarcerated; Katherine escapes with the help of Jake. The candle in the darkness still flickers. 
With a little license, the eyeglasses become a master clue not just for Jake in his investigation, but for us as well in our current inquiry regarding Chinatown, for the film itself can also be regarded as having a bifocal vision. Towne's conception of Chinatown as outlined in his original drafts did not survive production. In the end, it was subject to the particular narrative and thematic interests of director Polanski. Whereas Towne's classicist impulse dictated that he stay within the bounded conventions of the material, Polanski proved he was willing to cross those boundaries at the proper moment in order to transcend the limits imposed by a strict adherence to generic conventions. He saw no reason to remain loyal to the spirit of the hardboiled genre and, in particular, no reason to preserve the few shreds of optimism in Towne's version the film. Although Towne's script remained mostly intact throughout production, Polanski insisted on a different ending, one that would fundamentally alter Towne's faithfully articulated vision of the hardboiled genre, including its scopic assumptions. In Polanski's version—the one that survived production-Evelyn dies; Noah is granted, with the tacit consent of the authorities, possession of Katherine; and Jake's actions, although geared towards saving both Evelyn and the girl, unwittingly contribute to Noah's victory over both. The question now becomes why and in what manner their respective visions for the film diverge.

Towne's script was drawn from two specific sources. The first, as noted, was the genre of hardboiled fiction. The second were the historical records of real-life personalities and events connected to the development of Los Angeles in the 1920s and 1930s, particularly in the context of water management. What I would like to underscore 
is that both sources for Towne's vision of the film, however based the latter was on historical detail, were removed from his personal experience. For its screenwriter, Chinatown existed mainly in his imagination. Towne constructed the story with recourse to the hardboiled genre's history, narrative conventions, and formal possibilities, in addition to research material concerning Los Angeles, but without any grounding in the reality of his everyday life. If it was personal for Towne it was only on the level of artistic integrity, and accounts of his feud with both director and producer Robert Evans over the script changes do not reveal anything more than a frustration on his part to the perceived disfigurement of his story at the hands of Polanski. ${ }^{147}$ Some of the darker elements in Towne's original draft may have been inspired by actual, contemporaneous socio-political events in the American cultural landscape, but there is nothing to indicate that Towne was funneling his own experiences into the script, nothing to indicate a personal connection with either the events in his narrative or the characters that inhabit his story.

Unlike Towne, Polanski at some point seems to have made the film personal, grounded in some of the darker, more horrifying, but nonetheless real events of his life. Because he grew up as a Jew in Poland during the Second World War, Polanski experienced first hand the horrors unleashed by the Nazis. In addition to the general misery they inflicted on him and his family, Polanski's mother died at their hands. Years later, tragedy struck the director again when his wife Sharon Tate was ritualistically murdered by the Manson family. No one can accurately gauge the effects such traumatic

${ }^{147}$ The best account of this saga can be found in: David Thomson, The Whole Equation (New York: Alfred A. Knopf, 2005). 
experiences have on an individual's artistic temperament and, although scholars frequently make the connection, Polanski himself has never explicitly linked these horrors with his approach to Chinatown. However, he did, on occasion, consciously draw upon these experience as fodder for his creative choices. For example, in his autobiography Polanski admits to being "inspired" by his recollection of the way SS officers raided and searched his home during the occupation in Poland for his staging of a comparable scene in Macbeth (1971), ${ }^{148}$ the first film he made following the murder of his wife. Whatever the cause, Polanski refused to deliver a film with what he called a "happy ending." In elaborating his differences with Towne, he stated categorically that "Evelyn had to die," and that the film's "dramatic impact would be lost unless audiences left their seats with a sense of outrage at the injustice of it all." ${ }^{\text {"149 }}$ Thus, at some point Polanski decided that the fantasy concocted by Towne must give way to, what was for him, brutal reality.

The final sequence of the film, as conceived by Polanski, not only purges Chandler's romantic pessimism, it does so in part by reconfiguring the hardboiled genre's scopic assumptions. It is during this last sequence that the film's theme of visuality, woven so deferentially by Towne into the narrative, is resolved according to the director's sensibilities, not the writer's. We have noted that, up to its culminating sequence, the film was meant to reproduce faithfully the visual mode of hardboiled fiction: although Jake misperceives important clues throughout, he proves to have the exceptional cognitive skills common to hardboiled detectives. Jake was, in the end,

\footnotetext{
${ }^{148}$ Roman Polanski, Roman By Polanski (New York: William Morrow and Company Inc., 1984), 333.

${ }^{149}$ Ibid., 348.
} 
constructed by Towne with the capacity to solve the mystery and enact justice, if only in an equivocal way. For Polanski, however, that kind of romantic pessimism rang false, so he designed an ending that expressed, instead, an unequivocal nihilism.

It is Polanski who insisted on using the location of Chinatown for the climax of the film. Towne never meant for any scene to take place in that particular quarter of Los Angeles. As it is referred to in the script by various characters, Chinatown was less a physical space than an enigmatically abstract one. "You can't always tell what's going on there," says Jake at one point. Although Towne deliberately invokes a place that is fundamentally inscrutable, he argued with Polanski over its inclusion as a practical location; such an obscure place was meant to remain remote and unvisited. In Polanski's hands Chinatown becomes the physical correlate to his dark vision-a stage upon which to mount his nihilistic spectacle. In Lyon's words, Chinatown is, for Polanski, an "arena of random, meaningless, and omnipotent malevolence where the worst that can conceivably occur will." ${ }^{, 150}$ It is in Chinatown where Towne's carefully constructed visual design breaks down. Evelyn not only dies there, her eye is obliterated by a bullet as she tries to escape with Katherine. Upon seeing the horror of her mother's ocular injury, Katherine stares, transfixed and screaming. She is finally led away by Noah, who covers her eyes to spare her the sight. The image is that of the depraved Noah taking firm possession of Katherine while she cries out in dismay, her gaze not only averted, but forcibly obscured. As designed by Polanski, Chinatown becomes a labyrinth of diabolical opaqueness.

\footnotetext{
${ }^{150}$ Lyons, 53.
} 
It is also in Chinatown where the limits of Jake's cognitive powers are revealed. Fictional detectives are granted their superlative clarity of vision for the express purpose of demystifying a mystery, for tying together seemingly random fragments into a meaningful whole and then retaining its image in their mind for inspection. Jake, it bears repeating, is a proven detective in this regard. However, his cognitive prowess is surpassed by the bifocal eyesight of Noah, whose duplicitous vision has the capacity to see Hollis as both a business and a sexual rival, Evelyn as both daughter and lover, Katherine as both daughter and granddaughter, and the public water as his private domain. Jake's vision, as exceptional as it might be, proves to be woefully inadequate when confronted by such an indomitable scopic perspective. At one point, Noah, from a visually superior perch, states these prescient words to Jake: "You may think you know what you're dealing with, but believe me, you don't." Yet Jake fails to heed this warning. In the course of his investigation, he discovers, as one commentator states, "greed and corruption so pervasive, a corporate conspiracy so immense, that no individual can get to the bottom of it, or do anything about it, and almost anybody may be complicit in it." $" 151$ Even Noah, who occupies the web's dark heart is not fully aware of its reach. "I have no idea," he answers truthfully when asked by Jake about the size of his wealth.

What Jake experiences in Chinatown is a precipitous loss of bearings not unlike the kind Jameson describes in relation to the postmodern experience. According to Jameson, postmodernism increases the complexity of the network of systems with which we must contend to the point of unintelligibility. The space it creates cannot be

\footnotetext{
${ }^{151}$ Gamel, 158.
} 
cognitively processed into a meaningful map, and without the agency afforded by knowledge of the system, paralysis ensues. Chinatown is just such a space. Outside of Chinatown, Jake traverses the urban landscape with relative ease and aptitude. It is only when he enters the postmodern dimension of Chinatown that his powers fail him. Once there, Jake, like the postmodern subject postulated by Jameson, loses all sense of direction. Jake even acknowledges the paralysis his predicament entails. What can he do in Chinatown? The mantra he mutters is "as little as possible." According to Jameson, it is Capital itself that designs a system of such complexity that it is beyond our capacity to counteract it. In the film, this function is reserved for Noah, the embodiment of rapacious Capital and the only figure with any agency in that dark place. He owns Katherine, he owns the water, he owns the police, and, ultimately, he owns Jake. And he exploits them all. How does one even begin to map the obscure system designed by this monster of Capital?

Towne's original ending, had it been adopted, would have resolved the theme of visuality more equivocally. Evelyn's eye, in addition to her life, would have been spared. Katherine would not have witnessed her mother's horrible death, nor would she have fallen blindly into Noah's clutches. Jake would have fulfilled his role as detective and claimed a partial victory over the forces of darkness. Overall, the scopic uncertainty of the hardboiled genre that informs the majority of the finished film would have remained intact. In contrast, Polanski's script changes presuppose the supremacy of the impenetrable labyrinth. The ending he designed imposed a postmodern order on the narrative that refutes the innate capacity of the detective to provide transparency, 
illumination, and coordinates to what is, in principle, inherently inscrutable. Towne may have given Evelyn a flawed iris, but it is Polanski who decimates it with a bullet.

Just as the hardboiled genre adapted the scopic assumptions of classical detective fiction in the wake of a growing distrust of Cartesian Perspectivalism, so too did antiocular films like The Long Goodbye and Blade Runner adapt the scopic assumptions of hardboiled fiction to accommodate a denigrated visual order. Postmodernism rejects the enlightened epistemological basis of detective fiction that posited a causal link between seeing and knowing. Both films reflect this anti-ocular premise. On the other hand, Chinatown ultimately exhibits a bifocal vision. Through his changes to the ending of the film, Polanski imposed a dark, postmodern perspective on what was up to that point a traditional hardboiled story. Between the romantic pessimism of its writer and the obscure nihilism of its director, Chinatown has a visual orientation akin to a Janus figure, glancing both back towards an era of scopic uncertainty and forwards towards one of scopic incredulity. 


\section{Conclusion}

The framework devised for this thesis defines the historical development of detective fiction according to shifts in how it expresses the relationship between sight and knowledge--its "scopic assumptions." As a genre, detective fiction can be viewed as a meditation on the supposedly causal relationship between sight and the acquisition of knowledge espoused by Enlightenment principles. In light of this framework, this genre's fundamental conventions are determined by its underlying scopic assumptions. Through its plot construction, it dramatizes how we link seeing and knowing, and through its thematic interests, it explores the ensuing implications. Detective fiction also registers modifications in the visual order via modifications to its underlying scopic assumptions; it adapts its conventions and thematic interests to accommodate new modes of observation.

The dominant scopic regime that emerged from the Enlightenment was Cartesian Perspectivalism, a visual order that forged a robust link between seeing and knowing while adopting a distant, disincarnated perspective. A close study of The Murders in the Rue Morgue confirms that Cartesian Perspectivalism was brought to its logical conclusion in fictional, dramatic terms with the publication of Edgar Allan Poe's detective fiction. Poe's story and its two sequels established the prototype for the classical detective story, a narrative form that validates Cartesian Perspectivalism and its premise that complete knowledge can be attained by adopting its particular mode of observation. Hardboiled fiction assumed a different perspective. As the hegemonic 
authority of Cartesian Perspectivalism faltered, uncertainty penetrated the visual order. The detective genre registered this uncertainty via modifications to the scopic assumptions of the classical detective story. The result was hardboiled fiction, a more tentative detective form that bridged the scopic gap established by its predecessor. However, the price it paid for these innovations was the admission of ambiguity, complexity, and uncertainty into its conventions. Postmodernism brought with it a deep mistrust of vision that, at its extreme, entailed its denigration. In the postmodern era, antiocular detective films like The Long Goodbye and Blade Runner incorporated this mistrust into their scopic assumptions, inverting the visual configuration of Poe's inaugural detective stories. These films fatefully interrogate the underlying premise of detective fiction that one can master the world through visual means.

Between traditional hardboiled fiction and its postmodern counterpart, Chinatown occupies a unique place. Although other films of that time exhibit an unqualified antiocular perspective, Chinatown's visual orientation is dual in nature, having underlying scopic assumptions that exhibit both uncertainty and incredulity. Because of its twin perspective, Chinatown stands as a pivotal detective story. It links two decisive stages in the historical development of the detective genre by elaborating the scopic assumptions of each and articulating the passage between them. Among detective fiction, Chinatown is the only film to capture the transition from one scopic regime to the next in one coherent text. 
Because of the breadth of the central topic examined in this thesis, practical considerations forced the neglect of several related areas of inquiry that are implied by the research. Although they are not elaborated in this account, they may be suitable topics for future study. One that I would like briefly to touch upon is organized around the ontological implications that arise from detective fiction's scopic assumptions.

In their account of modern scopic regimes, both Martin Jay and Jonathan Crary discuss vision's instrumental role in an epistemology that provides a coherent, unified subjectivity. Their work adds credence to the commonplace that equates private "eye" with private "I." With its indebtedness to Cartesian Perspectivalism, the classical detective story validates a notion of a visually-constituted subject. Hardboiled fiction is more ambiguous in this regard because of its tentative scopic assumptions; subjectivity for the hardboiled detective is determined by a pervasive uncertainty. The scopic assumptions that inform the end of Chinatown suggest that a visually-constituted subject is illusory. The postmodern hyperspace of Chinatown constitutes an obscurity so impenetrable that what is ultimately at stake is Jake's sense of his own being. His scopically-generated agency, so confidently marshaled outside the dark confines of Chinatown, dissolves when he enters that place, leaving him completely powerless to enact his will.

Although this issue is broached in Chinatown, it is more thoroughly explored in Blade Runner, a detective film whose central thematic concerns are organized around the existential implications of a visually-based epistemology. The opening shot of the film is a God's-eye view of futuristic cityscape-an infernal congestion suggestive of the 
apocalypse. It is followed by the image of an eye, which fills the entire screen and reflects the infernal cityscape while both returning and mirroring our gaze. In the scene that follows, we are introduced to a procedure that can apparently identify artificial human beings, or "replicants," via their ocular responses to highly personal questions. The questions are "designed to provoke an emotional response," in a way that exposes the false humanity of the replicants. The procedure incorporates a device designed with some kind of video apparatus whose role is to focus on the eye. There are several closeups of eyes mediated through this technology, each framed identically to the image of the eye in the opening sequence. The replicants subjected to this procedure in Blade Runner cannot fool the apparatus; in each case, their eyes betray their non-human identity.

The film's detective, Deckard, is tasked with tracking down and executing these artificial beings, but his investigation leads to the implication that he himself might be one of them. There have been several official edits of the film, some more suggestive than others that Deckard is also a replicant, without any one version offering unequivocal confirmation. Yet it is this very ambiguity of Deckard's status as either replicant or human that defines the film's scopic assumptions. In Blade Runner, we are presented with a detective figure whose investigations into the mysterious identities of others have led him to investigate himself as the most mysterious identity of all.

The account I have presented also admits another blind spot that further research could potentially elucidate. Although this study covers several variations of detective fiction, it is by no means exhaustive. The classical and hardboiled traditions of the genre 
were dominant in their day, but the postmodern era has produced a proliferation of trends, none of which can be called definitive. The most relevant have been chosen in accordance with the stipulated framework, but out of necessity others have been omitted. In particular, there are three of note that warrant more scrutiny.

The first of these trends involves mockery of the detective. This trend was initiated by The Long Goodbye, appeared in a few other 1970s detective films like Night Moves and The Late Show, and culminated in a string of television shows in the 1980s. A partial list of these programs includes Police Squad, Remington Steele, Moonlighting, and, the one which most explicitly satirized the hardboiled detective, Sledgehammer. These programs portrayed the detective as a combination of incompetent, impotent, and inadequate. However, by the end of the 1980 s, this trend has retreated, indicating that the narrative possibilities of such an approach were quick to be exhausted.

The second trend portrays the detective as righteous vigilante, and is exemplified by the Dirty Harry and Death Wish franchises. This trend can be read as a reaction against the perceived relativism entailed by the postmodern lack of a fixed organizing principle. It reflects a desire to counter such relativism by asserting, or reasserting, an inflexible moral code. The cognitive limitations that films like Chinatown and The Long Goodbye expose are thus overcome in the vigilante detective film through a kind of moral rearmament, one that is expressed through righteous violence. It should come as no surprise that we can read something of the American culture wars that resulted from the transformative years of the 1960s in the tension between this trend and the one 
represented by Chinatown and The Long Goodbye. In this sense, both have political implications that transcend their detective genre roots.

The last trend neglected in this study that I would like to touch upon briefly is supernatural detective fiction. Long anathema to the genre, the supernatural has become a staple element of detective fiction since The X Files first incorporated it into the form. This influential program spawned several imitators, including The Lone Gunman, Millennium, Buffy the Vampire Slayer, Ghost Whisperer, and Medium, to cite only a few examples. The implications for detective fiction represented by this trend are rather profound since it inverts the genre's foundational privileging of Logos over Mythos. Yet, of all the trends to have emerged in the postmodern era, supernatural detective fiction has enjoyed the most durability.

It is too soon to determine whether one trend will emerge to have more historical significance over the others, or whether this will be remembered as the era in which the detective genre succumbed to a polyscopic visual order, with no particular type dominating. My own continuing investigations into detective fiction, and hopefully those of other scholars as well, may eventually shed some light on these issues. Until then, I will have to remain in the dark. 


\section{Bibliography}

Bazin, André. What is Cinema? Translated by Hugh Gray. Berkley: University of California Press, 1967.

Benjamin, Walter. Charles Baudelaire: A Lyric Poet in the Era of High Capitalism. Translated by Harry Zoane and Quintin Hoare. London: New Left Books, 1973.

Biensen, Sheri Chinen. Blackout: World War II and the Origins of Film Noir. Baltimore: The John Hopkins University Press, 2005.

Borde, Raymond and Etienne Chaumeton. A Panorama of American Film Noir: 19411953. Translated by Paul Hammond. San Francisco: City Lights Books, 2002.

Cawelti, John. "Chinatown and Generic Transformation in Recent American Films." In Film Theory and Criticism Introductory Readings, edited by Gerald Mast, Marshall Cohen, and Leo Braudy, 498-511. New York: Oxford Press, 1992.

Chandler, Raymond. Four Complete Philip Marlowe Novels. New York: Avnel Books, 1964.

Letter to Jamie Hamilton. 21 March 1949. In The Raymond Chandler Papers, edited by ed. by Frank Macshane and Tom Hiney. Atlantic Monthly Press, 2000.

. "The Simple Art of Murder." Atlantic Monthly, December, 1944, 53-59.

Chesterton, G.K. The Defendant. Letchwork: The Temple Press, date unknown.

Clark, T.J. The Painting of Modern Life: Manet and His Followers. Princeton: Princeton University Press, 1984.

Cooper, Stephen. "Sex/Knowledge/Power in the Detective Genre," Film Quarterly 42, no. 3 (Spring 1989): 23-31.

Crary, Jonathan. Techniques of the Observer: On Vision and Modernity In the Nineteenth Century. Cambridge Mass.: MIT Press, 1990.

D'Alembert, Jean le Rond. Preliminary Discourse to the Encyclopedia of Diderot. Translated by Richard N. Schwab and Walter E. Rex. New York: Bobbs-Merrill, 1963. 
Descartes, René. The Philosophical Writings of Descartes. Vol 2. Translated by John Cottingham, Robert Stoothoff, and Dugald Murdoch. Cambridge: Cambridge University Press, 1984.

Dickos, Andrew. Street With No Name: A History of the American Film Noir. Lexington: The University Press of Kentucky, 2002.

Doyle, Sir Arthur Conan. The Hound of the Baskervilles. New York: Dodd, Mead \& Company, 1968.

. A Study in Scarlet. London: Wordsworth Editions, 2000.

Eaton, Michael. Chinatown. London: BFI Publishing, 1997.

Foucault, Michel. Discipline and Punish: The Birth of the Prison. Translated by Alan Sheridan. New York: Vintage Books, 1979.

Galperin, William. “'Bad for the Glass': Representations and Filmic Deconstruction in Chinatown and Chan is Missing," MLN 102, no. 5 (Dec. 1987): 1151-1170.

Gamel, Mary-Kay. "Chinatown." In Classical Myth and Culture in the Cinema, edited by Martin M. Winkler. Oxford: Oxford University Press, 2001.

Gardner, Paul. “'Long Goodbye' Proves a Big Sleeper Here," New York Times, November 8, 1973, p. 59.

Hammett, Dashiell. The Maltese Falcon and The Thin Man. New York: Vintage Books, 1964.

Heidegger, Martin. "The Age of the World Picture" In The Question Concerning Technology and Other Essays, translated and edited by William Lovitt. New York: Harper \& Row, 1977.

Horowitz, Mark. "Fault Lines," Film Comment 26, no. 6 (November 1990): 52-58.

Ivins Jr., William M. On the Rationalization of Sight. New York: Da Capo Press, 1973.

Jameson, Fredric. Postmodernism or the Cultural Logic of Late Capitalism. Durham: Duke University Press, 1991.

Janson, H.W. The History of Art. 4th ed. New York: Prentice Hall Inc., 1991.

Jay, Martin. Downcast Eyes: The Denigration of Vision in Twentieth-Century French Thought. Berkeley: University of California Press, 1993. 
. Marxism and Totality: The Adventures of a Concept from Lukács to Habermas. Berkeley: University of California Press, 1984.

Jonas, Hans. "The Nobility of Sight." In Philosophy and Phenomenological Research 14, no. 4 (June 1954): 507-519.

Lyons, Donald. "Flaws in the Iris," Film Comment 29, no. 4 (July 1993): 44-53.

Lyotard, Jean-François. Peregrinations: Law, Form, Event. New York: Columbia University Press, 1988.

. The Postmodern Condition: A Report on Knowledge. Translated by Geoff Bennington and Brian Massumi. Minneapolis: University of Minnesota Press, 1984.

Man, Glenn. Radical Visions: American Film Renaissance, 1967-1976. Wesport, Conn.,: Greenwood Press, 1994.

Merleau-Ponty, Maurice. "The Eye and the Mind." In The Primacy of Perception, translated by James M. Edie. Evanston: Northwestern University Press, 1964.

Most, Glenn W., and William W. Stowe, eds. The Poetics of Murder: Detective Fiction and Literary Theory. New York: Harcourt Brace Jovanovich, 1983.

Murch, A.E. The Development of the Detective Novel. Port Washington: Kennikat Press, 1968.

Oliver, Bill. "The Long Goodbye and Chinatown: Debunking the Private Eye Tradition," Literature/Film Quarterly 3, no. 3 (Summer 1975): 242-248.

Ong, Walter J. The Presence of the Word. New York: Global Academic Publishing, 2000.

Pierce, C.S. "Logic as Semiotic: The Theory of Signs." In The Philosophy of Peirce: Selected Writings, edited by J. Buchler, 98-119. London: Harcourt, Brace and Company, 1940.

Poe, Edgar Allen. Tales of Mystery and Imagination. Oxford: Oxford University Press, 1996.

Polanski, Roman. Roman Polanski. New York: William Morrow and Company Inc., 1984.

Porter Roy. The Enlightenment. Basingstoke, Hampshire: Palgrave, 2001. 
Schivelbusch, Wolfgang. Disenchanted Night: The Industrialisation of Light in the Nineteenth Century. Translated by Angela Davies. Berkeley: University of California Press, 1988.

Schrader, Paul. "Notes on Film Noir." In The Film Genre Reader II. Edited by Barry Keith Grant, 169-182. Austin: University of Texas Press, 1995.

Simmel, Georg. The Sociology of Georg Simmel. Translated and edited by Kurt H. Wolff. New York: Free Press, 1950.

Sontag, Susan. On Photography. New York: Anchor Books Doubleday, 1977.

Starobinski, Jean. The Invention of Liberty, 1700-1789. Translated by Bernard C. Swift. Geneva: Skira, 1964.

Symons, Julian. Blood Murder: From the Detective Story to the Crime Novel: A History. New York: Viking Peguin Inc., 1985.

Sypher, Wylie. Literature and Technology: The Alien Vision. New York: Vintage Books, 1971.

Thompson, Jon. Fiction, Crime, and Empire: Clues to Modernity and Postmodernism. Champaign: University of Illinois Press, 1993.

Thomson, David. The Whole Equation: A History of Hollywood. New York: Alfred A. Knopf, 2005.

Voltaire. A Philosophical Dictionary. Translated and edited by Theodore Besterman. New York: Penguin Books, 1972. 